\title{
A NOVEL STUDY OF THE INTERRELATIONSHIP OF SEASONALITY, SATELLITE DATA AND WEED COMPOSITIONAL CHANGES OF THE AGRO-ECOLOGICAL SYSTEM OF GUJRAT, PAKISTAN
}

\author{
KHAN, A. M. ${ }^{1 *}-$ QURESHI, R. ${ }^{1}-$ SAQIB, $Z^{2}{ }^{2}-$ HABIB, T. ${ }^{3}-$ ILYAS, M. ${ }^{1}-$ MAQSOOD, M. ${ }^{1}-$ \\ KOSAR, R. ${ }^{1}$ - AKRAM, M. ${ }^{1}$ - RAHIM, B. Z. ${ }^{4}$ \\ ${ }^{1}$ Department of Botany, Pir Mehr Ali Shah Arid Agriculture University, Rawalpindi, Pakistan \\ ${ }^{2}$ Department of Environmental Science, International Islamic University, Islamabad, Pakistan \\ ${ }^{3}$ Department of Botany, University of Azad Jammu \& Kashmir, Muzaffarabad, Pakistan \\ ${ }^{4}$ Department of Botany, University of Balochistan, Quetta, Pakistan
}

*Corresponding author

e-mail: arshadbotanist@gmail.com; phone: +923335217235

(Received 26 $6^{\text {th }}$ Feb 2018; accepted $10^{\text {th }}$ May 2018)

\begin{abstract}
The adverse effects of the weed flora on the agricultural yield are well documented. In an agroecosystem, weed species distribution pattern depends on both surrounding environment and farming practices. This first ever study was designed to compare and determine the weed species richness, distribution pattern and their ecologically meaningful groups in wheat and maize field of Gujrat, Pakistan. In this study, seasonal variation variable and satellite derived measurements like normalized difference vegetation index (NDVI), normalized difference moisture index (NDMI) and topographic wetness index (TWI) were calculated for each vegetation sample and their contribution towards explaining variations in the weed species data was tested by using direct unimodal ordination method. Phytosociological data was collected from 50 crop fields ( 25 each from wheat and maize fields during winter and monsoon season respectively) comprising of 250 sub-samples/plots (size $1 \times 1 \mathrm{~m}$ ) during 2016. The results of Monte Carlo testing and cluster analysis showed that there were four statistically significant weeds groups (i.e. 1. Anagallis-Medicago-Phalaris or AMP-Wheat weed group; 2. Chenopodium-Convolvulus-Vicia or CCVWheat weed group; 3. Cyperus Malva-Amaranthus or CMA-Maize weed group; 4. Cannabis-CynodonDigera or CCD-Maize weed group). A total of 60 weed species were recorded and the majority of them belongs to Poaceae and Amaranthaceae families. The majority of weed species flowered during monsoon season whereas therophytic life form and microphyllous leaf size categories were the most dominant. The highest mean weed diversity, NDVI and NDMI values were recorded for the weed communities of maize fields whereas the higher mean TWI value was recorded for the weed groups of wheat fields, suggesting strong linkage with the local climatic conditions. Canonical correspondence analysis (net effects) suggested that sum of local climatic conditions (seasonality variable) was found to be the most important in controlling the variations in the weed species data followed by longitude and altitude variables and least by the NDVI, NDMI and TWI. It is concluded that effective weed management activities are required to enhance the yield of these two important crops in the area. Thus, further studies related to determination of weed types and their distribution pattern by using factors like fertilization (type, timing, quantity), wheat and maize cultivar, land preparation (types, timing and intensities), soil management, pesticides (usage, type, quantity, quality), irrigation (type like rain-fed, tube-well, canals; timing, quantity), socio-economic and anthropogenic activities, and their relationship with the yield variable on temporal and spatial scales are recommended for this agro-ecosystem of the study area.
\end{abstract}

Keywords: wheat and maize crops, normalized difference vegetation index, normalized difference moisture index, topographic wetness index, cluster analysis and ordination 


\section{Introduction}

The weed species though might be useful as ecosystem services providing agents but due to their competitive nature (Anderson, 1996), their occurrence in a maintained agroecosystem is considered hazardous for agricultural yield. The control and management of weed species in such systems is desirable and practiced since centuries. Pakistan is a rapidly developing country and agriculture sector provides leading share in country's economy. A large number of factors like inappropriate land preparation, modest understanding about crop varieties, seed quality under varied micro-habitats amongst the farmers, water logging, salinity, fertilizers and pesticides types, their effectiveness including high cost and poor availability, agri-land fragmentation, small holdings, availability of water for irrigation and poor weed management are responsible of reduced agricultural production. The latter factor is most important and can reduce the crop yield from $15-50 \%$, thus these are undesired plant species growing in any agroecosystem (Qureshi and Bhatti, 2001). They consume three to four time more soil nutrients than a weeds free crop. Their seeds becomes dormant and remained viable for many year, and their seed coat can resist adverse climatic and edaphic conditions (Qureshi and Bhatti, 2001). Similarly even some alien invasive weeds like Parthenium hysterophorus L. (Compositae) are threatening local biodiversity and agricultural production (Shabbir and Bajwa, 2006). The weed species synthesize and deliver different phytotoxins or allelochemicals in surrounding, thus causing increase in the costs of different cultural practices, decrease the effectiveness of agricultural tools, fertile lands and germination capability of crops seeds (Algandaby and Salama, 2016).

Agriculture is the major source of earning livelihood in Pakistan whereas wheat is a globally important Rabi cereal crop including Pakistan. It is cultivated at variety of micro-habitats from the sea level to high altitude mountains (Hussain et al., 2004). About more than $1 / 3^{\text {rd }}$ of the world population is dependent on this crop for their dietary mainstay (Jakhar et al., 2005). But national losses in wheat yield due to weed infestation estimated about 28 billion/year in Pakistani rupees (Hussain et al., 2004). Wheat yield increases in the country during the last few decades but still its average yield/ha is far behind (only 30 to $35 \%$ of potential yield) than the developed countries (Hussain et al., 2007). Total global wheat production was about 724 million tons during 2017, whereas it was only about 25.5 million tons in Pakistan although cultivated on an area of 8494 million hectares. Thus, Pakistan average wheat yield was $2585 \mathrm{~kg} / \mathrm{ha}$, and was very low compared to European Union, India, China and Russian Federation (Iqbal et al., 2018).

Maize (Zea mays L.) is an annual, cross pollinated, short day plant. It was grown on an area of 132 million hectare with yield of 570 metric tons globally (Ashique et al., 1997). Within Pakistan, it is continuously gaining significant position in crop husbandry. This species has higher yield potential and complete its life cycle within short duration. During 2012-13, Pakistan maize yields was about 36.581 metric tons and cultivated on the total area of 0.981 million hectare, whereas during 2017, the production was about 5.8 million tonnes (FAO, 2017). Many weed species as tough competitors, compete with the maize crop for available resources (Malik et al., 2006; Ahmad et al., 2016a). Weed species can severely reduce maize production during initial stage of growth and ultimately effect yield. The loss of maize yield due to weed infestation was recorded quite high (about 16-40\%) in Pakistan (Ahmad et al., 2016b).

By using satellite remote sensing (SRS) data, monitoring of vegetation change pattern can be conveniently understood and improve our knowledge about the spatial distribution and characteristics of vegetation of any area. Similarly, changes in the land 
use pattern can be used to investigate the relationship between population density and vegetation pattern changes on both spatial and temporal scale. The SRS data can illustrate the type, size and condition of the vegetation of any area. Sultana et al. (2014) found a significant correlation between the normalized difference vegetation index (NDVI) and yield behavior of the different wheat cultivars and nitrogen fertilization, and thus concluded that NDVI is a good tools for wheat yield prediction especially at crop maturity stage.

No record exists for such ecological exploration, and to fill this gap, this study was aimed to answer the following research questions for the first time from the study area. 1. What are the number of ecologically meaningful weed groups of wheat and maize crops, community types, composition and diversity? 2. What are the indicators species and their strength of association with their associated groups? 3. What about the leading weed families, genera, species, weeds flowering response (timing), life form and leaf size spectra? 4. How seasonality (wheat plots $=$ winter $=1$; maize plots $=$ monsoon $=2$ ), topographic and SRS variable are related amongst themselves, and with the weed species distribution pattern in the study area? Although this study, targeted the agroecological system of wheat and maize fields, the collected SRS data will be used to explore the pattern of relationship between SRS variables and weed distribution pattern (if any) instead of crop yield attributes in the study area. This study will serve as the first baseline survey and also be useful for future related agro-ecosystem explorations in the region.

\section{Materials and Methods}

\section{Study Area}

Gujrat district is located in the Punjab province, Pakistan and between two famous rivers, the Chenab and Jhelum. It is situated between the $73^{\circ} 33^{\prime}$ to $74^{\circ} 24^{\prime}$ E longitude and $32^{\circ} 24^{\prime}$ to $33^{\circ} 10^{\prime} \mathrm{N}$ latitude. It is bounded by the Jhelum district towards the west and northwest, district Sialkot on the east, district Gujranwala on the southeast, district Mandi Bahauddin on the southwest, district Mirpur and Bhimber of Azad Jammu and Kashmir on the north and northeast (Fig. 1). It is further administratively divided into 4 tehsils (Sarai-Alamgir, Kharian, Gujrat and Jalalpur Jattan), 119 union councils and 1065 villages. The total land area of the district is $3192 \mathrm{~km}^{2}$. The study area is comprised of many historic towns like Jalalpur Jattan, Lalamusa, Kharian, SaraiAlamgir, Dinga and Kunjah. The total human population of the district is 2.756 million (i.e. Urban 827396; Rural 1928714; Household 442399), and comprising of $43 \%$ urban population. The human density is about 863 persons $/ \mathrm{km}^{2}$ (DCR, 2017), whereas population of Gujrat city is about 0.39 million. The district has moderate climate with hot summer and cool winter. The highest temperature during the peak of summer shoot up to $50^{\circ} \mathrm{C}$ whereas minimum temperature during winter peak might fall below $2^{\circ} \mathrm{C}$. The average rainfall varies from $1000 \mathrm{~mm}$ to $500 \mathrm{~mm}$ in the different parts of the district, usually higher in the northern parts and decreases continuously towards the southern parts (Parvaiz, 2014). Monthly mean climatic data of temperature and rainfall variations of the study area is given in Table 1. The total area under cultivation was about 0.321 million hectare $(25.68 \%$ ), out of this, wheat was cultivated on about 158.2 hectare and its production was about 1.85 tons/ha. Maize crop was sporadically 
cultivated in the study area. A very small area (31000 ha) is being irrigated through canal irrigation system whereas majority of area under cultivation is always irrigated through tube wells (Anonymous, 2018).

The study area is represented by sub-tropical deciduous vegetation with Acacia modesta Wall., Acacia nilotica (L.) Delile, Albizia lebbeck (L.) Benth., Cassia fistula L., Dalbergia sissoo DC., Melia azedarach L., and Morus alba L. as indicator tree species, and Datura innoxia Mill., Dodonaea viscosa (L.) Jacq., Justicia adhatoda L., and Ziziphus nummularia (Burm.f.) Wight \& Arn. were important components of shrub layer. Soil of the study area is poor in calcium carbonate (about 6\%) and its texture varied from sandy loam to clayey loam, and located in the lower end of piedmont plains. The bedrock comprised of semi-consolidated and weakly cemented, coarse sandstone with underlying clay and shale layers (Ullah et al., 2007). These materials were deposited probably during Late Pleistocene and Subrecent periods. Application of advanced weed management activities for the crop protection were uncommon in the study area. Only $6 \%$ farmers claimed the use of these protocols especially the use of weedicides (Trade name: Buctril Super; Puma Super; Logran and Topik etc.) during different stages of crops growth and development. The majority of farmers belonging to remote areas are still using traditional weed management practices like timing and number of field ploughs, and weed up-rooting (by hand).
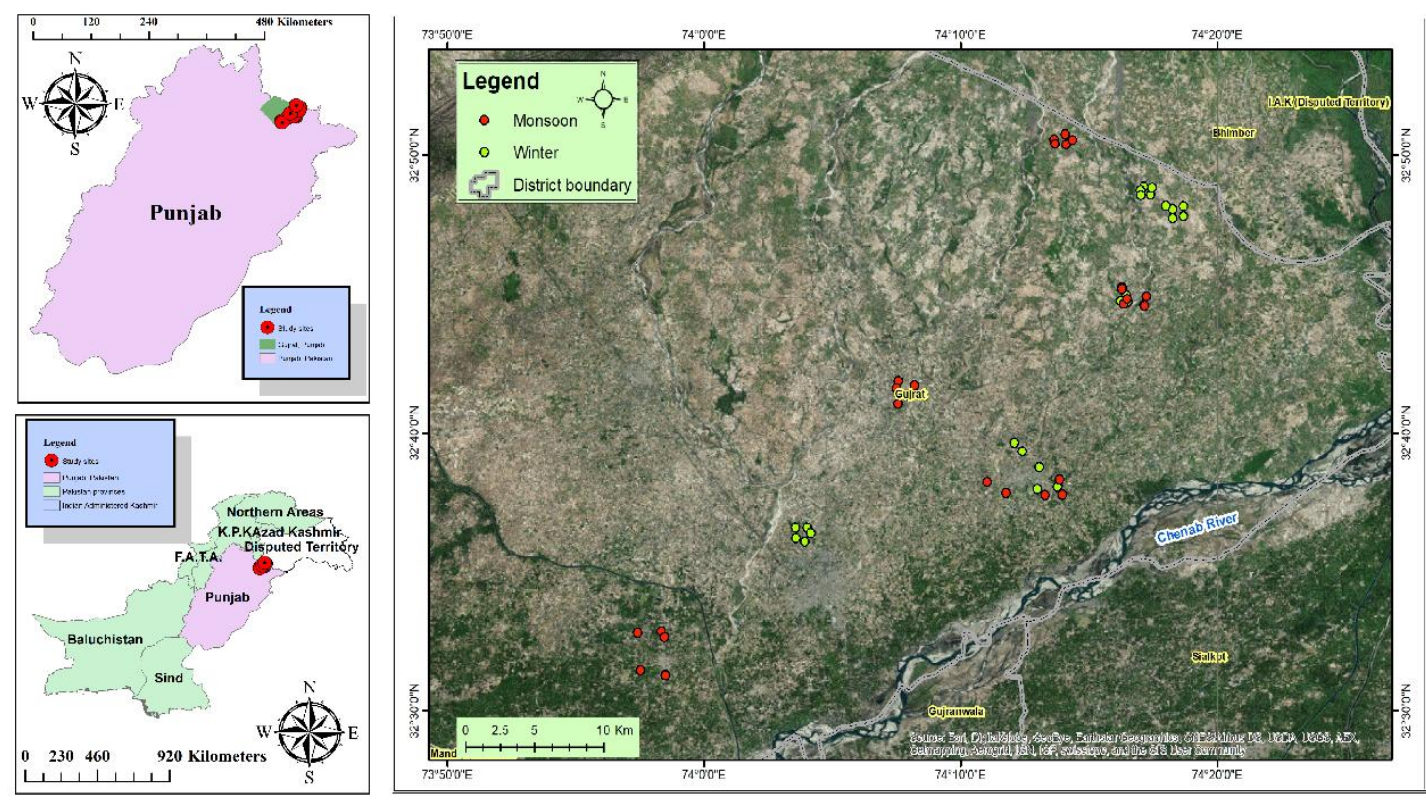

Figure 1. GIS map of district Gujrat, Pakistan showing distribution of weeds samples collected from the wheat and maize crops (winter and monsoon seasons respectively) during 2016.

\section{Plant Collection and Sampling Protocols}

The detailed floristic surveys were conducted during each month from JanuaryDecember, 2016. The voucher specimens were collected, pressed, dried and mounted on standard sized herbarium sheets. The same were identified by using the available regional taxonomic literature and online floral databases (Stewart, 1972; Nasir and Ali, 1971-1995; Ali and Qaiser, 1995-2009; EFLORAS, 2012; TROPICOS, 2012). After 
identification, all the familial and species binomials were copied from the website; www.theplantlist.org (TPL, 2013) to attain global homogeneity with respect to updated taxonomic views (Khan et al., 2015; 2016). The same were deposited in the PMAS Herbarium of Department of Botany, Pir Mehr Ali Shah Arid Agriculture University Rawalpindi, Pakistan for future references and record. The Raunkiaer's life form, leaf size, local names and flowering duration of each weed species were recorded and calculated for each weed community.

For vegetation sampling, stratified random method was adopted. For this, five different sites were randomly selected to record weed composition of each of bread wheat (during winter season) and maize crops (monsoon season) in the study area. Followed by this, at each site, five different fields were randomly selected and again, at each field, five plots/quadrats (size; $1 \times 1$ meter) were studied for collection of density, frequency and cover data of the weed species. The averaged values of these variable were then used to get their relative values, which were further used to get importance value index (IVI) value for each weed species (Iqbal et al., 2018). Thus, a total of 50 weed samples comprising of 250 plots [ 25 wheat weed samples: 5 sites $\times 5$ fields $\times 5$ plots $=$ 125 plots were studied during January-February and the same number of samples/subsamples were recorded from maize fields during July-August, 2016] were studied in the area.

\section{Satellite Data}

Satellite derived measurements related to 50 studied field locations of the study period, Landsat 8 (launched: 2013) satellite data was used that has spatial resolution of $30 \mathrm{~m}$. Two instruments viz. operational land imager (OLI) and thermal infrared sensor (TIRS) are onboard at Landsat 8 satellite, and the satellite collects images of the Earth with a 16-day repeat cycle. It provides 8-band multispectral scenes at 30 meter resolution along with band-8 (Panchromatic; 15 meter resolution) and two Thermal infrared sensor bands including TIRS- 1 and TIRS-2 as band-10 and 11 respectively at 100 meter resolution but are registered to and delivered with the 30-meter OLI data product as they were resampled to 30 meters to match multispectral bands. A median of the reflectance of all the images available for the study area and time period (after masking clouds) was created in Google Earth Engine and subsequent functional gradients/variables were derived from the median image. The reflectance values were corrected with respect to sun angle (Ganie and Nusrath, 2016). The following satellite measures were calculated;

The normalized difference vegetation index (NDVI) was calculated by using equation 1 as under;

$$
N D V I=\frac{N I R-R E D}{N I R+R E D}
$$

Where, NIR=Near-infrared=band 5 (wavelength vegetation emits) and RED=band 4 (wavelength vegetation absorb).

The NDVI value ranges between -1 to +1 . Higher NDVI value represent more abundance of live, healthy, green plants whereas small positive values $(\leq 0.1)$ depicts non vegetated areas such as barren land, rocks, sand, urbanized area, snow, and negative values by water bodies. 
The normalized difference moisture index (NDMI) estimate the levels of moisture in the vegetation. The NDMI was calculated by using corrected value of the band 5 (NIR), being sensitive to the reflectance of leaf chlorophyll content to the band 6 (Short-wave infrared-1; SWIR-1) and sensitive to the absorbance of leaf moisture as communicated by Gao (1996) and represented as equation 2 as under;

$$
N D M I=\frac{N I R-S W I R-1}{N I R+S W I R-1}
$$

Here, NIR=Near-infrared=band 5 and SWIR-1=Short-wave infrared-1=band 6 . NDMI value also ranges between -1 to +1 and the positive values represents moist areas and the negative ones to the non-moist features.

The location of sampling plots were determined by using Garmin, 76CSx handheld GPS device and two topographic variables namely altitude (meter) and topographic wetness index (TWI) were calculated through modelling $30 \mathrm{~m}$ digital elevation model (DEM) of the study area (download link; https://asterweb.jpl.nasa.gov/gdem.asp). The topographic wetness index (TWI) also known as compound topographic index (CTI) was developed by the Beven and Kirkby (1979), and shown in equation 3, to study the spatial scale effects on hydrological processes, flow paths, and biological processes like vegetation patterns and net primary productivity etc. The TWI was calculated as under as communicated by the Wilson and Gallant (2000).

$$
T W I=\ln \frac{\alpha}{\tan \beta}
$$

Where $\alpha$ is the local upslope area draining through a certain point per unit contour length and $\tan \beta$ is the local slope in radians. The TWI values were extracted from the sample point coordinate data using the distance-weighted average of the four nearest grid cells (bilinear interpolation) rather than a simple point extraction. ArcGIS was also used for mapping of bread wheat (winter) and maize (monsoon) crops weed samples distribution in the study area.

Table 1. Mean Monthly rainfall and temperature variations in the study area for the period of 5 years from 2012-2016.

\begin{tabular}{l|l|l|l|l}
\hline Months & Min. Temperature ${ }^{\circ} \mathbf{C}$ & Max. Temperature ${ }^{\circ} \mathbf{C}$ & Rainfall (mm) & Rainy days \\
\hline January & 11.8 & 22.6 & 21.422 & 4.2 \\
\hline February & 14.4 & 24 & 79.92 & 9.2 \\
\hline March & 19.8 & 28.6 & 100.656 & 12.2 \\
\hline April & 27.2 & 35.6 & 43.438 & 11.6 \\
\hline May & 33.6 & 42 & 29.782 & 11.8 \\
\hline June & 37 & 45.2 & 29.636 & 9.6 \\
\hline July & 35.4 & 43.2 & 92.666 & 20.4 \\
\hline August & 32.8 & 40.4 & 119.804 & 22.4 \\
\hline September & 31 & 39.2 & 119.682 & 10.4 \\
\hline October & 27.6 & 36.2 & 14.42 & 4 \\
\hline November & 20.6 & 30.2 & 2.658 & 2 \\
\hline December & 14.8 & 25.4 & 8.164 & 2.4 \\
\hline
\end{tabular}




\section{Statistical Analyses}

The decision about the number of ecological meaningful weed communities in the study area was determined by using the criteria as conveyed by Khan et al. (2017). For this, two to eight (2-8) possible groups were tested by using the Monte Carlo permutation test, and suitable level was selected, where mean p-value become minimized or significant species become maximized (McCune et al., 2002). The same appropriate grouping variable for the studied weed samples was further used in the hierarchical clustering (distance "relative euclidean"; linkage "ward") of studied samples and their associated weed species by using PC-ORD ver. 5 (McCune and Mefford, 2006), whereas the same for study sites was done by using $\mathrm{R}$ statistical software's (R Core Team, 2017). For this, package "decostand" was used to normalize vegetation data first followed by clustering through "hclust" package to use relative euclidean as distance method. For further confirmation, a non-parametric method (Multi-response permutation procedure "MRPP") as communicated by McCune et al. (2002) was used for pairwise comparasion of identified weed communities of wheat and maize crops and seasonality groups (i.e. winter and monsoon) to determine the significant difference with respect to their weeds composition. Indicator species analysis (Dufrêne and Legendre, 1997) was also performed to seek the indicator values of the weed species for the different groups defined by the cluster analysis. Species richness (Margalef, 1958), Shannon's diversity (Shannon and Weaver. 1949) Simpson's diversity index (1-D), Simpson's reciprocal diversity index (1/D) as conveyed by Magurran (1988) and evenness (Pielou, 1975) were calculated for each weeds community by using the "diversity(vegan)" package in $\mathrm{R}$ statistical software. The Kruskal-Wallis test was used to seek the significant difference in the weed communities with respect to their diversity, topographic and satellite-derived measurements like NDVI, NDMI and TWI variations. The direct unimodal ordination model (canonical correspondence analysis) was used to seek the weed species-environment relationship. The conditional or net terms effects of the studied variables and significance of constrained axes were tested by using the permutation test in Canoco ver. 5 (Ter Braak and Smilauer, 2012).

\section{Results}

A total of 60 weed species were recorded including 23 species in wheat, 28 in maize and 9 species as common in both types of fields in the study area. All these species (monocot 15; dicot 45) belongs to 26 plant families (monocot 3; dicot 23) and 52 genera (monocot 13; dicot 39) (Table 2). The leading plant family with maximum number of weed species was Poaceae (12 spp., 20\%) followed by Amaranthaceae (7 spp., 11.67\%), Compositae (6 spp., 10\%), Leguminosae (5 spp., 8.34\%), Solanaceae (4 spp., 6.67\%), Euphorbiaceae (3 spp., 5\%) and Convolvulaceae, Cyperaceae, Malvaceae with 2 species (3.34\%) each. Similarly the leading genus was Euphorbia (3 spp., 5\%) followed by Amaranthus, Chenopodium, Cyperus, Dactyloctenium, Medicago and Solanum with 2 species (3.34\%) each (Fig. 2). The majority of weed species were found in the flowering stage during the month of August (42 spp., 70\%) followed by July (41 spp., 68.34\%), September (41 spp., 68.34\%), June (35 spp., 58.34\%), May (30 spp., 50\%), April (27 spp., 45\%), October (26 spp., 43.34\%), March (24 spp., 40\%), February (12 spp., 20\%), January and November (8 spp., 13.34\% each) and least during the month of December (8 spp., 13.34\%) (Fig. 3). Based on Raunkiaer's life form, therophytes weed 
species were dominant (42 spp., 70\%) in the study area followed by hemicryptophytes (9 spp., 15\%), chamaephytes and lianas (3 spp., 5\% each), geophytes (2 spp., 3.34\%) and 1 weed species $(1.67 \%)$ of nanophanerophyte. Similarly, leaf size spectra studies depicted that microphylls weed species were dominant (25 spp., 41.67\%) in the study area followed by nanophylls (19 spp., 31.67\%), leptophylls (11 spp., 18.34\%) and least number of mesophyll (5 spp., 8.34\%) weed species were recorded (Fig. 8).

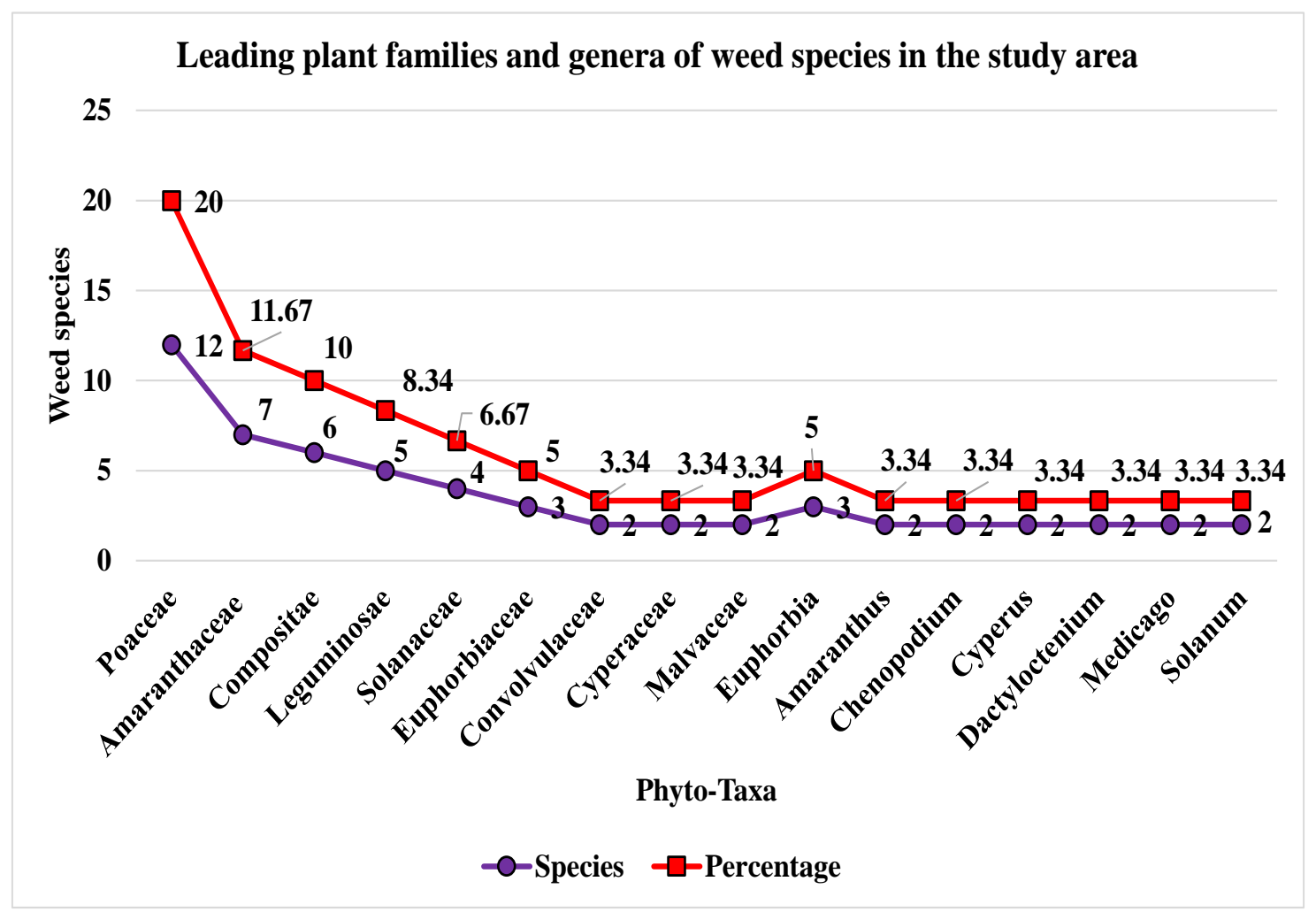

Figure 2. Leading plant families and genera of weed species of wheat and maize crops of Gujrat, Pakistan.

\section{Indicator Species Analysis and Weed Communities of the Study Area}

The number of ecologically meaningful weed groups were determined first by using Monte Carlo permutation test. The results for two to eight possible groups depicted that there were four (4) biologically meaningful weed communities of both wheat and maize crops in the study area. At fourth level, minimized mean p-value of 0.099 and maximized number of significant $\mathrm{p}$-values or 32 significant indicator weed species were recorded (Fig. 4). For classification, and to seek relationship of 50 weed samples and their associated 60 weed species, hierarchical clustering dendrogram was developed. This not only showed that 25 wheat weed samples were sufficiently different from the same number of maize weed samples with respect to their weed species composition but also showed that each of both these major clusters were further comprised of reasonably different two minor clusters or weed communities (Fig. 5). Thus, we recorded a total of four significant weed communities in the study area, two each for wheat and maize crop fields. Our results in this regard do not match with any of related studies from Pakistan, 


$$
-3003-
$$

as number of communities in this study are based on test statistics. The detail of each of wheat and maize communities is as under.

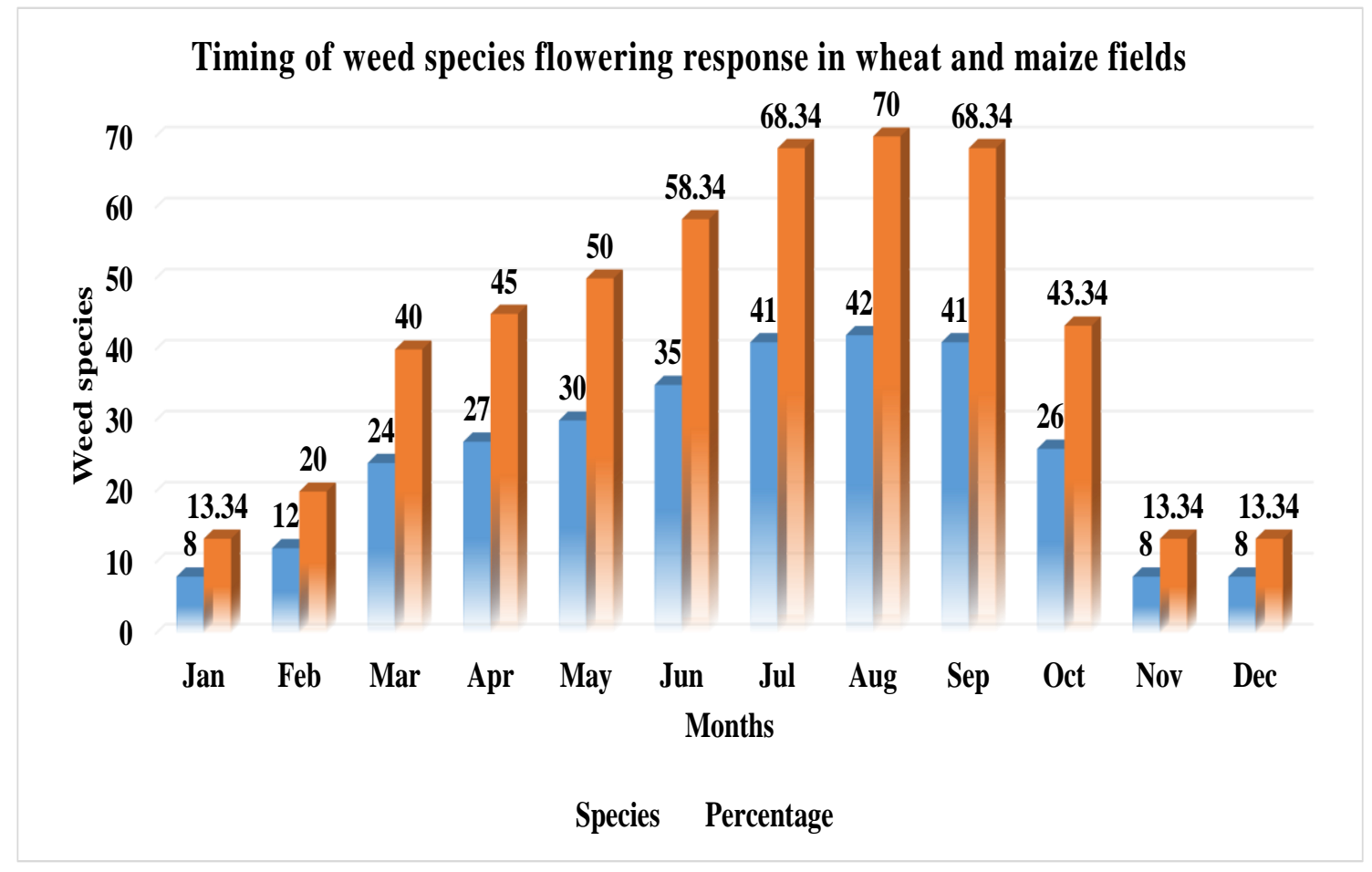

Figure 3. Number and percentages of weed species found in flowering stage during the study period.

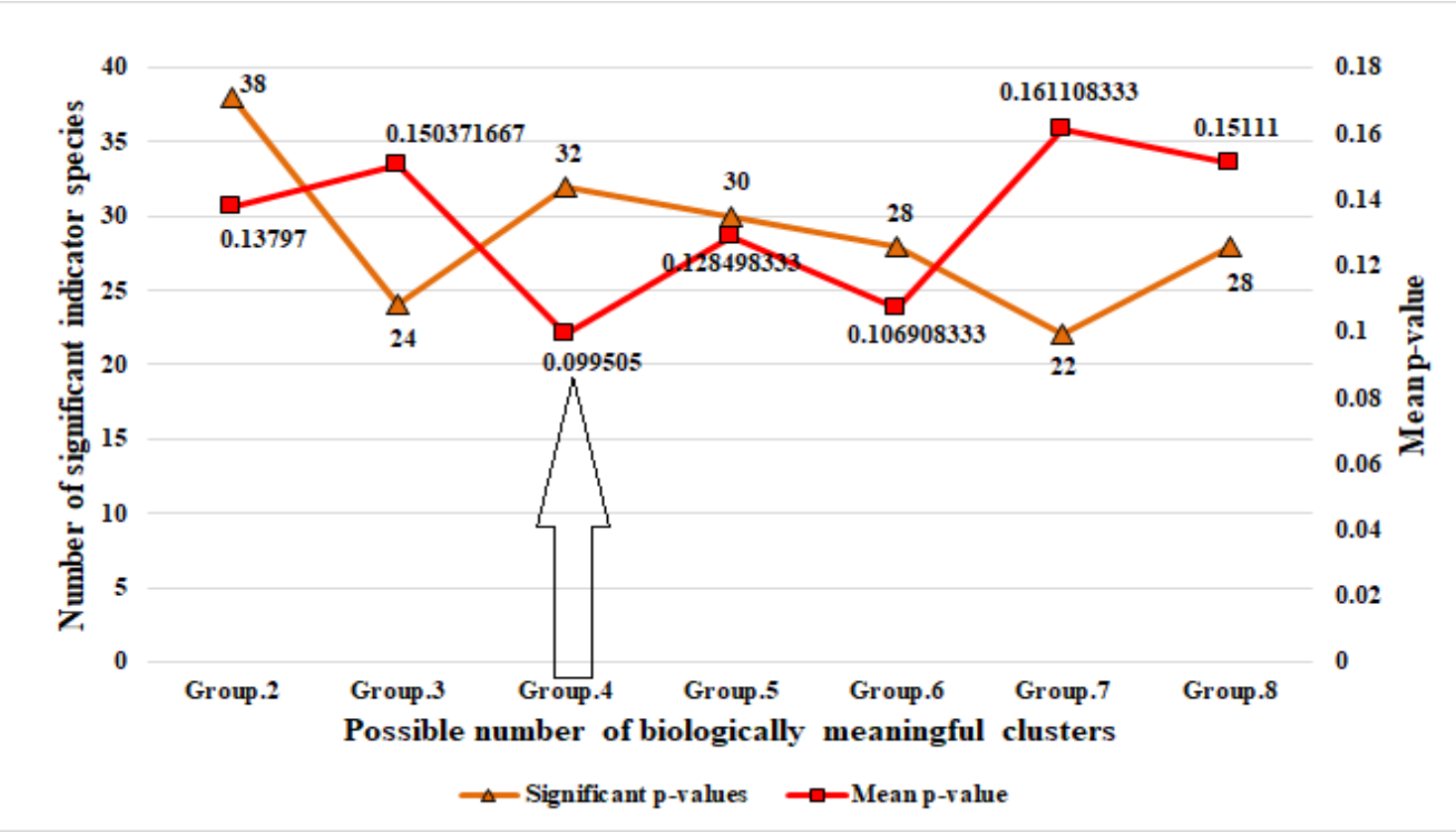

Figure 4. Number of statistically significant indicator species and associated mean p-value variations for 2 to 8 possible vegetation groups/clusters. 


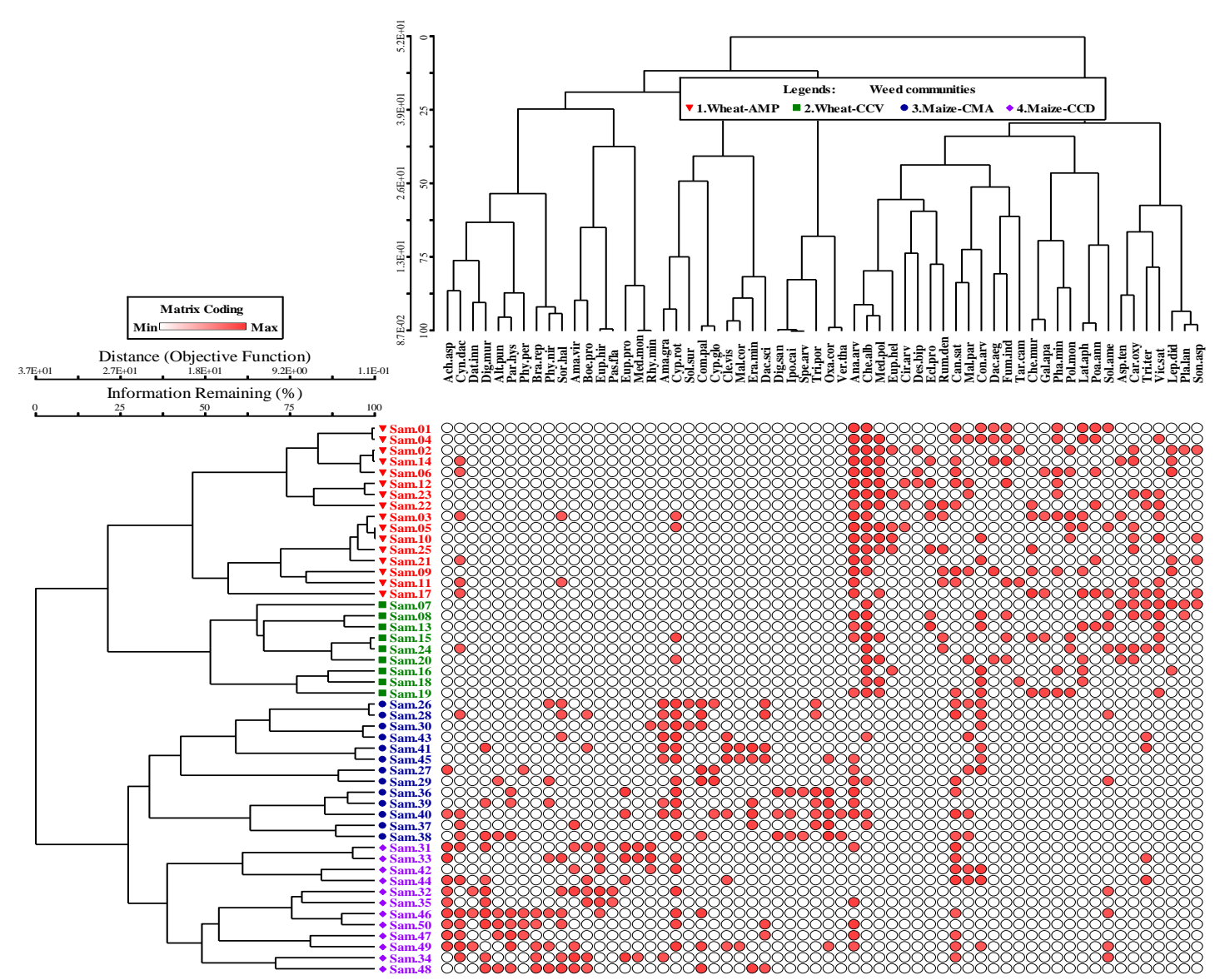

Figure 5. Hierarchical clustering of weed samples and their associated plant species, showing four biologically meaningful clusters/groups.

\section{Wheat Fields Communities}

\section{Anagallis-Medicago-Phalaris (AMP) Weed Community}

This, AMP weed community was recorded at 16 different wheat fields (samples) of Bhojpur, Ghaiyan, Jalalpur Jattan, Karianwala and Sabowal localities (Figs. 5 and 6). A total of 31 weed species including 15 indictor weed species were found associated with this group. There were 5 significant ( $\mathrm{p}$-value $\leq 0.05$ ) indicator species in this community. This group was dominated by Anagallis arvensis, Medicago polymorpha and Phalaris minor species having mean indicator value of 24.8, 17.1 and 13.1 respectively, thus named as AMP group. The other co-dominant species were Fumaria indica (12.9), Chenopodium murale (12.4), Lepidium didymum (12.3), Eclipta prostrata (12.2), Rumex dentatus (12), Poa annua (11.8) followed by less common species like Euphorbia helioscopia (11.1), Sonchus asper (10.6) and Dactyloctenium aegyptium (10.5). The rare species of this group were Cirsium arvense, Desmostachya bipinnata and Taraxacum campylodes with mean indicator value of 8.8 for each (Table 2). The number of weed species in all 16 studied fields varied from 7-14 with average count of $10.25 \pm 1.64$ species. Similarly the mean values of Margalef richness, Shannon's diversity $\left(\mathrm{H}^{\prime}\right)$, Simpson's diversity, reciprocal Simpson's diversity and Pielou evenness of this community were $2.69 \pm 0.39,2.08 \pm 0.18,0.84 \pm 0.04,6.66 \pm 1.36$ and $0.9 \pm 0.05$ respectively. It was studied at the mean elevation of $210.5 \pm 23.58 \mathrm{~m}$ a.s.l. which varied 
from 183-251 $\mathrm{m}$ a.s.1. It was located at latitude range of 32.61-32.82 DD (North) and longitude range of 74.06-74.32 DD (East). The mean NDVI, NDMI and TWI values were $0.38 \pm 0.05 \quad(0.31-0.49), \quad 0.15 \pm 0.05 \quad(0.05-0.25)$ and $7.83 \pm 0.2 \quad(7.47-8.15)$ respectively and found higher than the following weed community (CCV community) of wheat crop (Fig. 7). Raunkiaer's life form classification of weed species depicted the dominancy of therophytes ( $22 \mathrm{spp} ., 70.97 \%$ ), followed by hemicryptophytes (4 spp., $12.91 \%)$, whereas geophytes and lianas were represented by 2 species each $(6.46 \%)$ followed by chamaephytes ( $1 \mathrm{spp} ., 3.23 \%)$. Leaf size spectra showed the leading share of microphylls with 13 species (41.94\%) followed by leptophylls and nanophylls with 8 species each (25.81\%) whereas least number of mesophylls (2 spp., 6.46\%) were recorded in this community (Fig. 8).

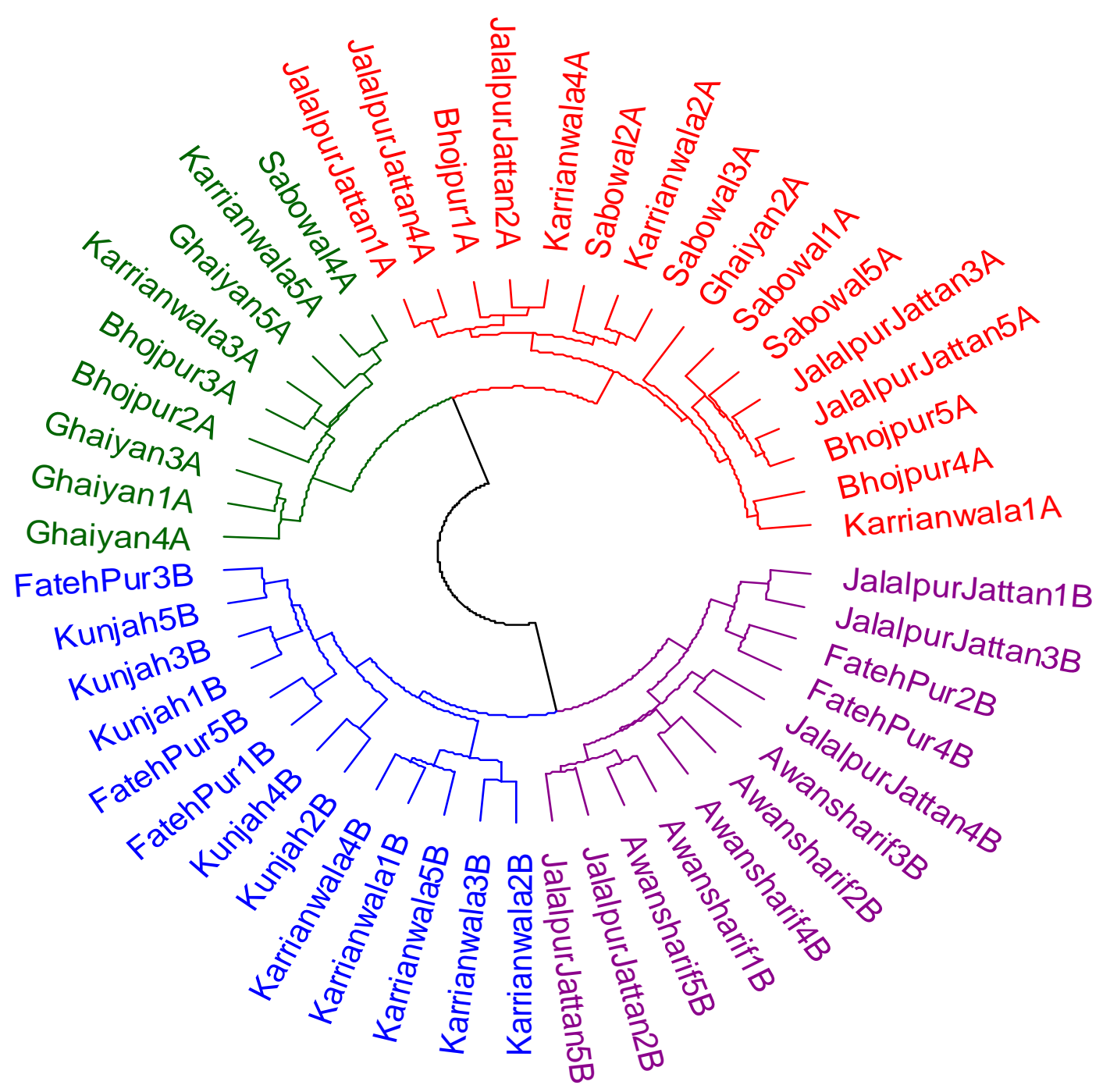

Figure 6. Fan (polar) shaped hierarchical clustering dendrogram showing grouping pattern of study sites $(\operatorname{Red}=A M P ;$ Green $=C C V ;$ Blue $=C M A$; Violet $=C C D$ weed community $)$.

\section{Chenopodium-Convolvulus-Vicia (CCV) Weed Community}

This community was recorded at 9 different wheat field of Bhojpur, Ghaiyan, Karianwala and Sabowal localities (Figs. 5 and 6). It was comprised of 28 weed species 
including 11 indicators which further includes 3 significant indicators species. The maximum mean indicator value (IV) was recorded for Chenopodium album (23.2), Convolvulus arvensis (18.3) and Vicia sativa (15.9) hence named as CCV community. Co-dominants of this group includes, Carthamus oxyacantha (15.1), Solanum americanum (15.1), Lathyrus aphaca (13.9), Tribulus terrestris (13.8) and Polypogon monspeliensis (12.6) whereas Galium aparine (10.5), Asphodelus tenuifolius (10.4) were recorded as less common species. Plantago lanceolata (8.8) was measured as rare species of this group (Table 2). Average species count of this community was $8.34 \pm 1.7$, and species number per sample/field ranges from 5 to 10. Values of Margalef richness, Shannon's diversity $\left(\mathrm{H}^{\prime}\right)$, Simpson's diversity, reciprocal Simpson's diversity and Pielou evenness of this community were $2.34 \pm 0.4$ (1.6-2.73), $1.93 \pm 0.22$ (1.51-2.27), $0.83 \pm 0.05$ (0.76-0.89), 6.09 $\pm 1.55(4.23-9.46)$ and $0.92 \pm 0.05$ (0.84-0.98) respectively. It was recorded at an average altitude of $235.34 \pm 22.4 \mathrm{~m}$ a.s.1. (186-260 $\mathrm{m}$ a.s.1.) and located at latitude range of 32.61-32.82 DD (North) and longitude range of 74.06-74.32 DD (East). Similarly, mean NDVI, NDMI and TWI values were $0.34 \pm 0.06(0.25-0.45)$, $0.12 \pm 0.05$ (0.04-0.19) and 7.93 \pm 0.51 (7.41-8.81) respectively (Fig. 7). Life form categorization of 28 weed species of this community depicted the leading abundance of therophytes (21 spp., 77.78\%) followed by hemicryptophytes (3 spp., 7.41\%), lianas (2 spp., $7.41 \%)$ and 1 species (3.71\%) each of chamaephytes and geophytes. Leaf size spectra results of this community again showed the dominancy of microphylls (12 spp., 42.86\%), followed by leptophylls and nanophylls with 8 species each (28.58\%) (Fig. 8).
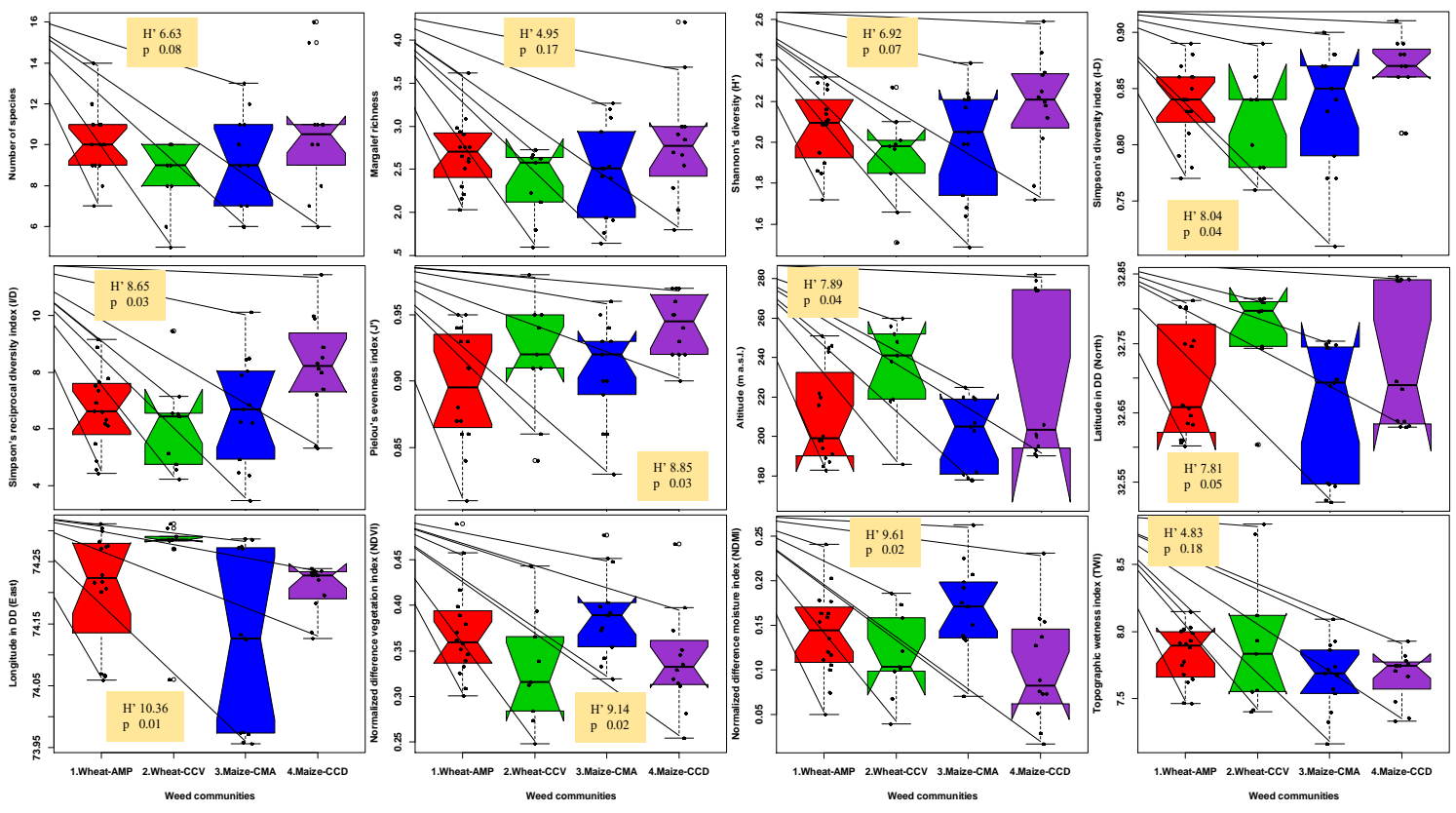

Figure 7. Boxplots with Kruskal-Wallis $H$ test and its associated p-values of environmental and biotic variables of weed communities in the study area

\section{Maize Fields Communities}

\section{Cyperus-Malva-Amaranthus (CMA) Weed Community}

This significant group was studied at 13 different maize fields of Fatehpur, Karianwala and Kunjah localities (Figs. 5 and 6). It includes 34 weed species including 16 indicator 
and 10 significant indicator of this group. Cyperus rotundus, Malva parviflora and Amaranthus graecizans subsp. silvestris were leading three species with mean IV of 20.1, 15.3 and 13.4 respectively. Co-dominant species were Commelina paludosa (13.3), Oxalis corniculata (12.4) whereas, common ones were Dactyloctenium scindicum (11.8), Trianthema portulacastrum (11.4), Cleome viscosa (11.2), Eragrostis minor (11.2), Cyperus glomeratus (9.7) and Malvastrum coromandelianum (9). Less common and rare ones includes Digitaria sanguinalis (8.9), Ipomoea cairica (8.8), Verbascum thapsus (8.1) and Spergula arvensis (8), Solanum surattense (7.9) respectively (Table 2). Average number of species were $9.24 \pm 2.16$ with range of 6 to 13 whereas Margalef richness, Shannon's diversity $\left(\mathrm{H}^{\prime}\right)$, Simpson's diversity, reciprocal Simpson's diversity and Pielou evenness values of this community were $2.48 \pm 0.53$ (1.64-3.27), $2.01 \pm 0.27$ (1.49-2.39), $0.84 \pm 0.06(0.71-0.9), 6.64 \pm 1.88(3.48-10.11)$ and $0.91 \pm 0.04(0.83-0.96)$ respectively. This group was studied at an average altitude of $201.24 \pm 18.2 \mathrm{~m}$ a.s.1. (178-225 $\mathrm{m}$ a.s.1.) and located at latitude range of 32.53-32.76 DD (North) and longitude range of 73.9674.29 DD (East). Mean NDVI, NDMI and TWI values of this group were $0.39 \pm 0.05$ (0.32-0.48), $0.17 \pm 0.05(0.08-0.27)$ and $7.67 \pm 0.26$ (7.17-8.1) respectively (Fig. 7). Results of Raunkiaer's life form classification of 34 weed species of this community suggested the maximum abundance of therophytes (23 spp., 67.65\%), followed by the hemicryptophytes (5 spp., 14.71\%), and 2 species (5.89\%) each for chamaephytes, geophytes and lianas species. Leaf size spectra results showed the dominance of microphyllous species (16 spp., 47.06\%), followed by nanophylls (11 spp., 32.36\%), leptophylls (4 spp., 11.77\%) and least species of mesophylls (3 spp., 8.83\%) (Fig. 8).

\section{Cannabis-Cynodon-Digera (CCD) Weed Community}

This community was recorded at 12 different maize fields of Awan Sharif, Fatehpur and Jalalpur Jattan localities (Figs. 5 and 6). It was comprised 31 weed species including 18 indicator and 14 significant indicator species. Three leading species were Cannabis sativa (21.2), Cynodon dactylon (18.5) and Digera muricata (15.1), hence renamed as CCD community. Associated co-dominants were Sorghum halepense (14.7), Achyranthes aspera (14.5), Boerhavia procumbens (12.8), Parthenium hysterophorus (12.7), Amaranthus viridis (12.1), Phyllanthus niruri (11.9) and Euphorbia hirta (11.6), whereas less common were Alternanthera pungens (11.1), Euphorbia prostrata (11.1), Brachiaria reptans (10.4), Rhynchosia minima (9.8) and Physalis peruviana (9.7). The rare species of this group were Datura innoxia (8.8), Medicago monantha (8.8) and Paspalidium flavidum (8.2) (Table 2). Mean species count of this community was $10.5 \pm 2.76$ with range of 6 to 16 weed species/sample, whereas Margalef richness, Shannon's diversity $\left(\mathrm{H}^{\prime}\right)$, Simpson's diversity, reciprocal Simpson's diversity and Pielou evenness values of this community were $2.81 \pm 0.64(1.8-4.21), 2.19 \pm 0.24$ (1.72-2.59), $0.87 \pm 0.03(0.81-0.91)$, $8.21 \pm 1.71(5.33-11.44)$ and $0.95 \pm 0.03$ (0.9-0.97) respectively. Mean elevation value was $230 \pm 39.83 \mathrm{~m}$ a.s.1. (190-282 $\mathrm{m}$ a.s.1.) and located at latitude range of 32.63-32.85 DD (North) and longitude range of 74.13-74.24 DD (East). Mean NDVI, NDMI and TWI values were $0.34 \pm 0.06(0.26-0.47), 0.11 \pm 0.06(0.02-0.24)$ and $7.68 \pm 0.18$ (7.33-7.93) respectively (Fig. 7). Therophytes were recorded dominant (20 spp., 64.52\%) in this community followed by hemicryptophytes ( 5 spp., $16.13 \%$ ), chamaephytes and geophytes with 2 species $(6.46 \%)$ each and one species $(3.23 \%)$ each of lianas and nanophanerophytes. Leaf size categorization of weed species of this community depicted that microphylls were dominant (15 spp., 48.39\%), followed by nanophylls (10 spp., $32.26 \%$ ), and three species (9.68\%) each of leptophylls and mesophylls (Fig. 8). 
Table 2. Results of indicator species analysis and weed species attributes from the study area.

\begin{tabular}{|c|c|c|c|c|c|c|c|c|c|c|c|c|}
\hline Family & Species Name / Voch. No. & Abbrev. & MG & $\begin{array}{l}\text { Obs. } \\
\text { IV }\end{array}$ & M/IV & SD & p-value & $\mathbf{L F}$ & $\mathbf{L S}$ & $\mathbf{F P}$ & Local Name & $\mathbf{S}$ \\
\hline Primulaceae & "Anagallis arvensis L. (RK/MA-2693/16) & Ana.arv & 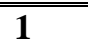 & 65.7 & 24.8 & 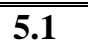 & 0.0002 & The & Nano & Feb-Mar & Billi Buti & $\overline{3}$ \\
\hline Leguminosae & $\begin{array}{l}\text { Medicago polymorpha L. (RK/MA- } \\
\text { 2688/16) }\end{array}$ & Med.pol & 1 & 46.7 & 17.1 & 5.9 & 0.0016 & The & Nano & Mar-May & Maina & 1 \\
\hline Poaceae & Phalaris minor Retz. (RK/MA-2660/16) & Pha.min & 1 & 26.8 & 13.1 & 5.6 & 0.0254 & The & Nano & Mar-May & Dumbi Sitti & 1 \\
\hline Papaveraceae & $\begin{array}{l}\text { Fumaria indica (Hausskn.) Pugsley } \\
\text { (RK/MA-2653/16) }\end{array}$ & Fum.ind & 1 & 20.5 & 12.9 & 5.95 & 0.1064 & The & Lept & Mar-Jun & Pitpaprra & 1 \\
\hline Amaranthaceae & $\begin{array}{l}\text { Chenopodium murale L. (RK/MA- } \\
\text { 2698/16) }\end{array}$ & Che.mur & 1 & 21.3 & 12.4 & 5.9 & 0.1024 & The & Lept & Jan-Jul & Karund & 1 \\
\hline Brassicaceae & Lepidium didymum L. (RK/MA-2706/16) & Lep.did & 1 & 15.3 & 12.3 & 5.85 & 0.2272 & The & Lept & Mar-Jun & Jangli Halian & 1 \\
\hline Compositae & $\begin{array}{l}\text { Eclipta prostrata (L.) L. (RK/MA- } \\
2701 / 16)\end{array}$ & Ecl.pro & 1 & 16 & 12.2 & 5.8 & 0.191 & The & Micr & Jun-Sep & Bhangra & 1 \\
\hline Polygonaceae & Rumex dentatus L. (RK/MA-2678/16) & Rum.den & 1 & 19 & 12 & 5.72 & 0.119 & Cha & Micr & May-Jun & Jangli Palak & 1 \\
\hline Poaceae & Poa аппиа L. (RK/MA-2676/16) & Poa.ann & 1 & 28.5 & 11.8 & 5.45 & 0.019 & The & Lept & Apr-Sep & Gha, Ghaas & 1 \\
\hline Euphorbiaceae & $\begin{array}{l}\text { Euphorbia helioscopia } \text { L. (RK/MA- } \\
\text { 2681/16) }\end{array}$ & Eup.hel & 1 & 23.6 & 11.1 & 5.5 & 0.033 & The & Micr & Jan-Jul & Chatri-Dudal & 1 \\
\hline Compositae & Sonchus asper (L.) Hill (RK/MA-2661/16) & Son.asp & 1 & 13.2 & 10.6 & 5.55 & 0.2653 & The & Micr & May-Oct & Dodak & 1 \\
\hline Poaceae & $\begin{array}{l}\text { Dactyloctenium aegyptium (L.) Willd. } \\
\text { (RK/MA-2674/16) }\end{array}$ & Dac.aeg & 1 & 18.4 & 10.5 & 5.52 & 0.0856 & The & Nano & Jul-Oct & Madhana Gaas & 1 \\
\hline Compositae & $\begin{array}{l}\text { Cirsium arvense (L.) Scop. (RK/MA- } \\
\text { 2709/16) }\end{array}$ & Cir.arv & 1 & 18.7 & 8.8 & 5.22 & 0.0572 & The & Meso & Aug-Oct & Kandiyari, Leh & 1 \\
\hline Poaceae & $\begin{array}{l}\text { Desmostachya bipinnata (L.) Stapf. } \\
\text { (RK/MA-2708/16) }\end{array}$ & Des.bip & 1 & 18.7 & 8.8 & 5.2 & 0.0574 & Hem & Micr & Jul-Oct & Dabh & 1 \\
\hline Compositae & $\begin{array}{l}\text { Taraxacum campylodes G.E.Haglund } \\
\text { (RK/MA-2682/16) }\end{array}$ & Tar.cam & 1 & 7.8 & 8.8 & 5.17 & 0.5079 & Hem & Micr & Mar-Sep & Hund & 1 \\
\hline Amaranthaceae & $\begin{array}{l}\text { Chenopodium album L. (RK/MA- } \\
\text { 2702/16) }\end{array}$ & Che.alb & 2 & 54 & 23.2 & 5.5 & 0.0004 & The & Micr & Jun-Oct & Bathwa, Bathu & 1 \\
\hline Convolvulaceae & $\begin{array}{l}\text { Convolvulus arvensis L. (RK/MA- } \\
\text { 2652/16) }\end{array}$ & Con.arv & 2 & 23.8 & 18.3 & 5.4 & 0.138 & Lia & Micr & May-Sep & $\begin{array}{l}\text { Lailee, Hiran } \\
\text { Padi }\end{array}$ & 3 \\
\hline Leguminosae & Vicia sativa L. (RK/MA-2655/16) & Vic.sat & 2 & 43.6 & 15.9 & 6 & 0.0014 & The & Lept & Mar-Aug & Rewari & 1 \\
\hline Compositae & $\begin{array}{l}\text { Carthamus oxyacantha M.Bieb. (RK/MA- } \\
2710 / 16 \text { ) }\end{array}$ & Car.oxy & 2 & 24.1 & 15.1 & 5.76 & 0.074 & The & Micr & Mar-Jun & Pohli & 1 \\
\hline Solanaceae & $\begin{array}{l}\text { Solanum americanum Mill. (RK/MA- } \\
\text { 2690/16) }\end{array}$ & Sol.ame & 2 & 12.1 & 15.1 & 5.63 & 0.6509 & The & Micr & Jan-Dec & Kach-Mach, Mako & 3 \\
\hline
\end{tabular}




\begin{tabular}{|c|c|c|c|c|c|c|c|c|c|c|c|c|}
\hline Family & Species Name / Voch. No. & Abbrev. & MG & $\begin{array}{l}\text { Obs. } \\
\text { IV }\end{array}$ & M/IV & SD & p-value & $\mathbf{L F}$ & $\mathbf{L S}$ & $\mathbf{F P}$ & Local Name & $\mathbf{S}$ \\
\hline Leguminosae & Lathyrus aphaca L. (RK/MA-2680/16) & Lat.aph & 2 & 20.9 & 13.9 & 5.81 & 0.1198 & Lia & Lept & Feb-Apr & Jangli Matar & 1 \\
\hline Zygophyllaceae & Tribulus terrestris L. (RK/MA-2664/16) & Tri.ter & 2 & 8.8 & 13.8 & 5.67 & 0.8014 & The & Nano & Jan-Dec & Bhakrra & 3 \\
\hline Poaceae & $\begin{array}{l}\text { Polypogon monspeliensis (L.) Desf. } \\
\text { (RK/MA-2667/16) }\end{array}$ & Pol.mon & 2 & 18.1 & 12.6 & 5.62 & 0.1478 & The & Nano & Mar-Jul & Malhar & 1 \\
\hline Rubiaceae & Galium aparine L. (RK/MA-2668/16) & Gal.apa & 2 & 14.2 & 10.5 & 5.47 & 0.1848 & The & Nano & Mar-Jul & Lahndra & 1 \\
\hline Xanthorrhoeaceae & $\begin{array}{l}\text { Asphodelus tenuifolius Cav. (RK/MA- } \\
\text { 2694/16) }\end{array}$ & Asp.ten & 2 & 27.2 & 10.4 & 5.43 & 0.0124 & The & Lept & Nov-Apr & Piyazi, Patakh & 1 \\
\hline Plantaginaceae & Plantago lanceolata L. (RK/MA-2659/16) & Pla.lan & 2 & 18.7 & 8.8 & 5.19 & 0.076 & Hem & Micr & Jul-Sep & Isabgool & 1 \\
\hline Cyperaceae & Cyperus rotundus L. (RK/MA-2662/16) & Cyp.rot & 3 & 53.4 & 20.1 & 5.5 & 0.0004 & Geo & Nano & Apr-Oct & Dheela & 3 \\
\hline Malvaceae & Malva parviflora L. (RK/MA-2705/16) & Mal.par & 3 & 14.2 & 15.3 & 5.8 & 0.4713 & The & Micr & Apr-Sep & Sonchal & 3 \\
\hline Amaranthaceae & $\begin{array}{l}\text { Amaranthus graecizans subsp. silvestris } \\
\text { (Vill.) Brenan (RK/MA-2669/16) }\end{array}$ & Ama.gra & 3 & 55.5 & 13.4 & 5.7 & 0.0004 & The & Micr & Jun-Sep & Lunak chellery & 2 \\
\hline Commelinaceae & $\begin{array}{l}\text { Commelina paludosa Blume (RK/MA- } \\
\text { 2703/16) }\end{array}$ & Com.pal & 3 & 32.4 & 13.3 & 5.67 & 0.0092 & The & Meso & Aug-Oct & Kanjuna, Churra & 2 \\
\hline Oxalidaceae & Oxalis corniculata L. (RK/MA-2673/16) & Oxa.cor & 3 & 44.7 & 12.4 & 5.93 & 0.0012 & Hem & Nano & Feb-Oct & Khatmit, Khatti & 2 \\
\hline Poaceae & $\begin{array}{l}\text { Dactyloctenium scindicum Boiss. } \\
\text { (RK/MA-2686/16) }\end{array}$ & Dac.sci & 3 & 20.4 & 11.8 & 5.38 & 0.0604 & Hem & Nano & Sep-Dec & Madhana Gaas & 2 \\
\hline Aizoaceae & $\begin{array}{l}\text { Trianthema portulacastrum L. (RK/MA- } \\
\text { 2671/16) }\end{array}$ & Tri.por & 3 & 46.2 & 11.4 & 5.62 & 0.0004 & The & Nano & May-Oct & Itsit & 2 \\
\hline Cleomaceae & Cleome viscosa L. (RK/MA-2657/16) & Cle.vis & 3 & 25 & 11.2 & 5.52 & 0.0264 & The & Micr & Jun-Aug & Gund-Buti, Bui & 2 \\
\hline Poaceae & Eragrostis minor Host (RK/MA-2695/16) & Era.min & 3 & 31.6 & 11.2 & 5.42 & 0.0084 & The & Nano & May-Sep & Bharbhuri & 2 \\
\hline Cyperaceae & Cyperus glomeratus L. (RK/MA-2679/16) & Cyp.glo & 3 & 30.8 & 9.7 & 5.25 & 0.0062 & The & Nano & Sep-Oct & Gooyaan & 2 \\
\hline Malvaceae & $\begin{array}{l}\text { Malvastrum coromandelianum (L.) Garcke } \\
\text { (RK/MA-2656/16) }\end{array}$ & Mal.cor & 3 & 12.1 & 9 & 5.04 & 0.2669 & The & Micr & Jun-Sep & Gogi Booti & 2 \\
\hline Poaceae & $\begin{array}{l}\text { Digitaria sanguinalis (L.) Scop. (RK/MA- } \\
\text { 2696/16) }\end{array}$ & Dig.san & 3 & 23.1 & 8.9 & 5.18 & 0.0296 & The & Nano & Jul-Sep & Moti khabbal & 2 \\
\hline Convolvulaceae & $\begin{array}{l}\text { Ipomoea cairica }(\mathrm{L} .) \text { Sweet (RK/MA- } \\
2670 / 16)\end{array}$ & Ipo.cai & 3 & 23.1 & 8.8 & 5.17 & 0.0296 & Lia & Nano & Jul-Oct & Aair & 2 \\
\hline Scrophulariaceae & Verbascum thapsus L. (RK/MA-2697/16) & Ver.tha & 3 & 15.4 & 8.1 & 4.69 & 0.1518 & The & Meso & Jun-Aug & Jangli Tumbaku & 2 \\
\hline Caryophyllaceae & Spergula arvensis L. (RK/MA-2651/16) & Spe.arv & 3 & 15.4 & 8 & 4.59 & 0.1384 & The & Lept & Mar-Apr & Not Available & 1 \\
\hline Solanaceae & $\begin{array}{l}\text { Solanum surattense Burm. f. (RK/MA- } \\
\text { 2707/16) }\end{array}$ & Sol.sur & 3 & 15.4 & 7.9 & 4.58 & 0.1432 & Hem & Micr & Jan-Dec & Kundiyara, Mokri & 2 \\
\hline Cannabaceae & Cannabis sativa L. (RK/MA-2685/16) & Can.sat & 4 & 26.7 & 21.2 & 5.5 & 0.1522 & The & Micr & Jul-Sep & Bhang & 3 \\
\hline Poaceae & Cynodon dactylon (L.) Pers. (RK/MA- & Cyn.dac & 4 & 34.4 & 18.5 & 5.7 & 0.0168 & Hem & Lept & Jan-Dec & Khabbal & 3 \\
\hline
\end{tabular}




\begin{tabular}{|c|c|c|c|c|c|c|c|c|c|c|c|c|}
\hline Family & Species Name / Voch. No. & Abbrev. & MG & $\begin{array}{l}\text { Obs. } \\
\text { IV }\end{array}$ & $\mathbf{M} / \mathbf{I V}$ & SD & p-value & $\mathbf{L F}$ & $\mathbf{L S}$ & $\mathbf{F P}$ & Local Name & $\mathbf{S}$ \\
\hline & $2663 / 16)$ & & & & & & & & & & & \\
\hline Amaranthaceae & $\begin{array}{l}\text { Digera muricata (L.) Mart. (RK/MA- } \\
2672 / 16 \text { ) }\end{array}$ & Dig.mur & 4 & 52.1 & 15.1 & 6.2 & 0.0002 & The & Micr & Jul-Sep & Tandla saag & 2 \\
\hline Poaceae & $\begin{array}{l}\text { Sorghum halepense (L.) Pers. (RK/MA- } \\
\text { 2665/16) }\end{array}$ & Sor.hal & 4 & 34.8 & 14.7 & 5.73 & 0.009 & Geo & Meso & May-Sep & Baru, Barwa & 3 \\
\hline Amaranthaceae & Achyranthes aspera L. (RK/MA-2691/16) & Ach.asp & 4 & 66.5 & 14.5 & 5.73 & 0.0002 & Cha & Micr & Jul-Oct & Puth-Kanda & 2 \\
\hline Nyctaginaceae & $\begin{array}{l}\text { Boerhavia procumbens Banks ex Roxb. } \\
\text { (RK/MA-2683/16) }\end{array}$ & Boe.pro & 4 & 43.3 & 12.8 & 5.71 & 0.001 & Hem & Micr & Aug-Sep & Sanati, Itsit & 2 \\
\hline Compositae & $\begin{array}{l}\text { Parthenium hysterophorus L. (RK/MA- } \\
\text { 2689/16) }\end{array}$ & Par.hys & 4 & 29.9 & 12.7 & 5.77 & 0.0186 & The & Nano & Apr-Oct & Sitara Buti & 2 \\
\hline Amaranthaceae & Amaranthus viridis L. (RK/MA-2704/16) & Ama.vir & 4 & 43.3 & 12.1 & 5.88 & 0.0016 & The & Micr & Mar-Oct & Ghanyar, Cholai & 2 \\
\hline Phyllanthaceae & Phyllanthus niruri L. (RK/MA-2692/16) & Phy.nir & 4 & 18.6 & 11.9 & 5.61 & 0.1266 & The & Lept & Aug-Sep & $\begin{array}{l}\text { Bahupatra, } \\
\text { Bhuiamla }\end{array}$ & 2 \\
\hline Euphorbiaceae & Euphorbia hirta L. (RK/MA-2684/16) & Eup.hir & 4 & 50 & 11.6 & 5.9 & 0.0006 & The & Nano & Jul-Dec & Dudhli & 2 \\
\hline Amaranthaceae & $\begin{array}{l}\text { Alternanthera pungens Kunth (RK/MA- } \\
\text { 2666/16) }\end{array}$ & Alt.pun & 4 & 24.8 & 11.1 & 5.5 & 0.021 & The & Micr & Aug-Oct & Kanda, Leh & 2 \\
\hline Euphorbiaceae & $\begin{array}{l}\text { Euphorbia prostrata Ait. (RK/MA- } \\
\text { 2699/16) }\end{array}$ & Eup.pro & 4 & 21.6 & 11.1 & 5.39 & 0.0592 & The & Lept & Jan-Dec & $\begin{array}{l}\text { Dudhli, Hazar } \\
\text { Dani }\end{array}$ & 2 \\
\hline Poaceae & $\begin{array}{l}\text { Brachiaria reptans (L.) C.A.Gardner \& } \\
\text { C.E.Hubb. (RK/MA-2675/16) }\end{array}$ & Bra.rep & 4 & 41.7 & 10.4 & 5.42 & 0.0012 & The & Micr & Jun-Oct & Sair, Kandeeri & 2 \\
\hline Leguminosae & $\begin{array}{l}\text { Rhynchosia minima (L.) DC. (RK/MA- } \\
\text { 2687/16) }\end{array}$ & Rhy.min & 4 & 20.7 & 9.8 & 5.37 & 0.047 & Cha & Micr & Feb-Apr & Turvel & 2 \\
\hline Solanaceae & Physalis peruviana L. (RK/MA-2677/16) & Phy.per & 4 & 21.1 & 9.7 & 5.27 & 0.0416 & The & Micr & May-Oct & Rasp berry & 2 \\
\hline Solanaceae & Datura innoxia Mill. (RK/MA-2654/16) & Dat.inn & 4 & 25 & 8.8 & 5.14 & 0.0164 & Nan & Meso & May-Oct & Datura & 2 \\
\hline Leguminosae & $\begin{array}{l}\text { Medicago monantha (C.A.Mey.) Trautv. } \\
\text { (RK/MA-2658/16) }\end{array}$ & Med.mon & 4 & 25 & 8.8 & 5.13 & 0.0158 & The & Nano & Mar-Apr & Jangli-Methi & 2 \\
\hline Poaceae & $\begin{array}{l}\text { Paspalidium flavidum (Retz.) A.Camus } \\
\text { (RK/MA-2700/16) }\end{array}$ & Pas.fla & 4 & 16.7 & 8.2 & 4.8 & 0.092 & Hem & Nano & Jul-Oct & Kangna & 2 \\
\hline
\end{tabular}

Legends: MG: Maximum Group; Obs. IV: Observed Indicator Value; M/IV: Mean Indicator Value; SD: Standard Deviation; LF: Life Form (Cha: Chamaephytes; Geo:

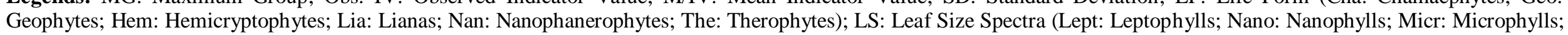
Meso: Mesophylls); FP: Flowering Period; S: Seasonality (1: Winter/Wheat; 2: Monsoon/Maize; 3: Both Season/Crops), Dominant species of each group are in bold. 


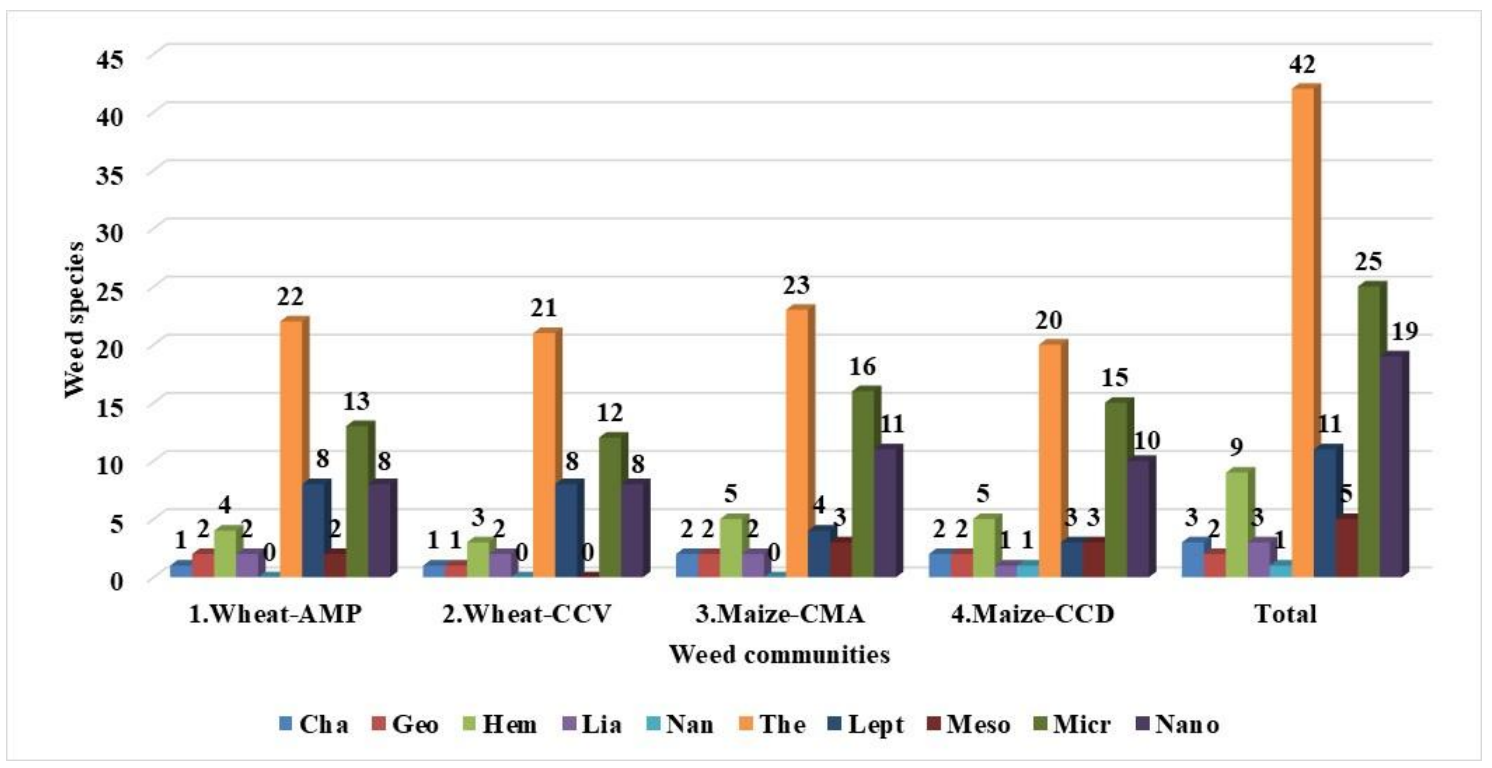

Figure 8. Raunkiaer's life forms and leaf size spectra of weed communities of the agroecological system of the study area (for abbreviation see legends of Table 2).

\section{Seasonal and Weed Communities Significance}

Pairwise comparasion of the two seasons (1. winter weed recorded in wheat fields; 2. monsoon weeds recorded in maize fields) and four weed communities were tested by using Multi-response permutation procedure (MRPP) test. The results depicted that all comparasion were significant ( $\mathrm{p}$-value $\leq 0.05$ ) with respect to weed composition of either both winter and monsoon seasons, and for four weed communities. Similarly, Avalues (within group agreement values) for all the comparasion were close to zero, thus depicting heterogeneity within group's equal's expectation by chance (Table 3).

Table 3. Multi-response permutation procedure (MRPP) test results for pairwise comparasion of the seasonal and weed communities groups.

\begin{tabular}{l|l|l|l}
\hline Groups compared & T & A & p-value \\
\hline Winter vs. Monsoon crop weeds & -24.376921 & 0.10575423 & 0.00000001 \\
\hline 1.Wheat-AMP vs. 2.Wheat-CCV & -8.68390727 & 0.07680782 & 0.0000053 \\
\hline 1.Wheat-AMP vs. 3.Maize-CMA & -15.84415686 & 0.15204394 & 0.00000002 \\
\hline 1.Wheat-AMP vs. 4.Maize-CCD & -14.83208997 & 0.13589612 & 0.00000006 \\
\hline 2.Wheat-CCV vs. 3.Maize-CMA & -11.16306984 & 0.12979608 & 0.00000077 \\
\hline 2.Wheat-CCV vs. 4.Maize-CCD & -11.35771764 & 0.13157812 & 0.00000128 \\
\hline 3.Maize-CMA vs. 4.Maize-CCD & -6.76188295 & 0.05187615 & 0.00000929 \\
\hline Overall & -21.086932 & 0.16229738 & 0.00000001 \\
\hline
\end{tabular}

\section{Canonical Correspondence Analysis (CCA)}

The gradient length of compositional response data was more than 4 SD unit long, thus unimodal direct ordination model (CCA) was selected along with down weightage of rare species. It was used to seek species-environment relationship, contribution and 
ranking of explanatory variables towards explaining variations in the species data. A total of 7 variables including seasonality (1=samples studied during winter in wheat fields; $2=$ samples studied during monsoon in maize fields), longitude, latitude, altitude, NDVI, NDMI and TWI were tested for their influence on species response data (samples, 50; species, 60). Total variation in the species data were 4.87, whereas explanatory variable account for 1.5487 or $31.8 \%$ variations. Eigenvalues of CCA axis1 and 2 were 0.73 and 0.25 respectively whereas species-environment relationship strength of the same was 0.9892 and 0.8912 respectively. Thus, first two constrained axes cumulatively explained $63.67 \%$ of fitted variations. Overall CCA model was significant thus further permutation test to seek the significance of explanatory variables and constrained axes (conditional or net term affects) were also performed. This depicted that four variables namely seasonality, longitude, altitude and latitude (in decreasing order) significantly ( $\mathrm{p}$-value $<0.05$ ) explained variations in the weed species data, whereas satellite derived variables were found non-significant in this regard. Out of 7, first three constrained axes were also found significant (Table 4). CCA graphical results (CCA biplot) for species and variables showed that seasonality gradient was the most important and clearly distribute weed species in the ordination space (right=winter/wheat weeds; left=monsoon/maize weeds; center=common weeds of both seasons) and strongly related with CCA axis-1 (Fig. 9). It was followed by the longitude (lower=high longitude species; upper= low longitude species) and related to CCA axis-2 and 3. The other important variables like altitude and latitude was found more related to CCA axis-4 $(r=0.74$ and 0.75 respectively), followed by NDVI with axis-5 $(r=0.51)$, NDMI with axis-6 $(r=-0.59)$ and TWI with axis-7 $(r=0.54)$.

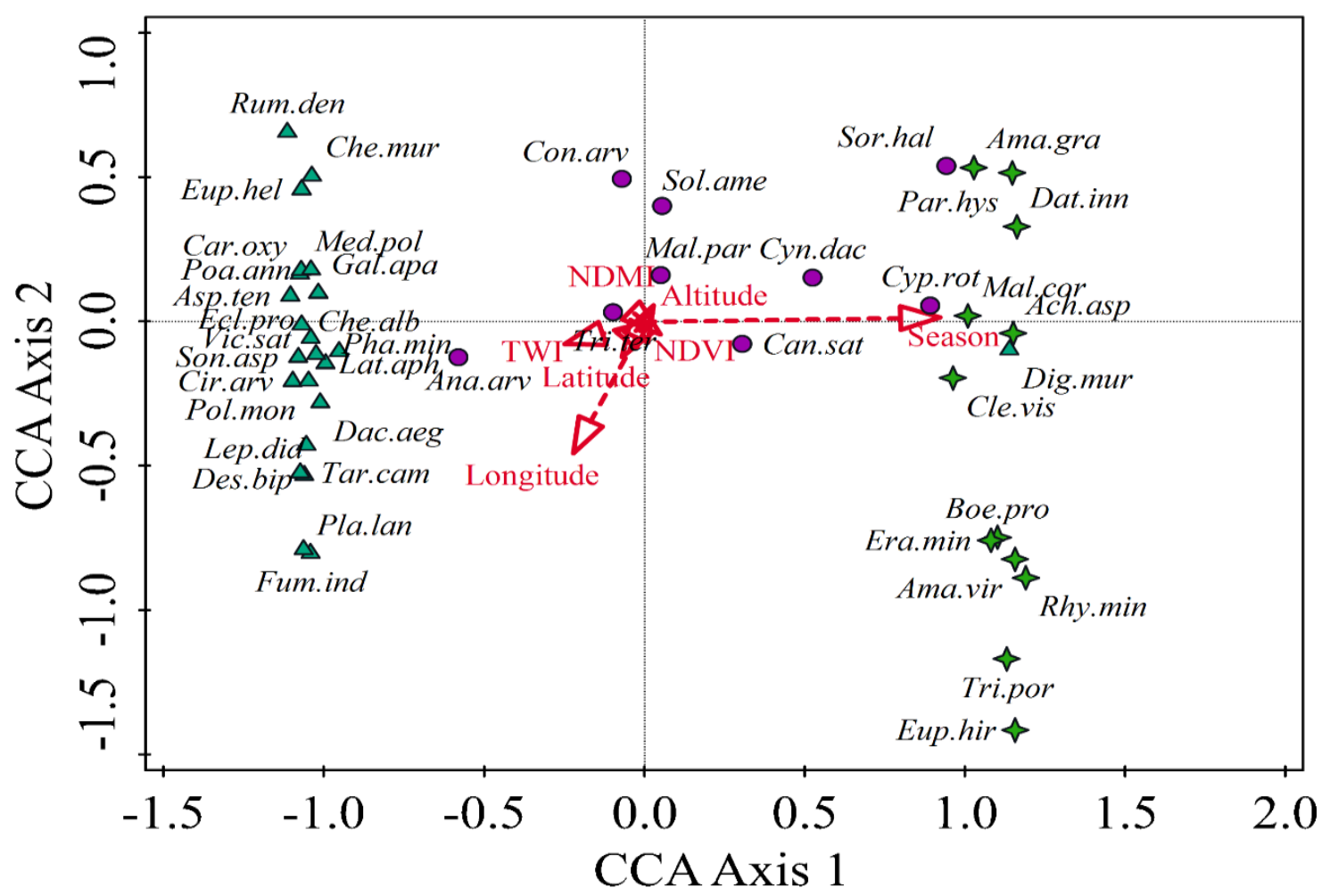

Figure 9. Canonical correspondence analysis biplot showing the weed species-environment relationships and species groups based on seasonality variable viz. Wheat weeds (left), Maize weeds (right) and common of both crops/seasons (center). 
Table 4. Significance testing results for the explanatory variables and CCA axes.

\begin{tabular}{l|l|l|l}
\hline Variables/CCA-axes & Explains \% & Pseudo-F & p-value \\
\hline Seasonality & 15 & 8.5 & 0.001 \\
\hline Longitude & 3.8 & 2.2 & 0.001 \\
\hline Altitude & 4.1 & 2.4 & 0.002 \\
\hline Latitude & 3.9 & 2.4 & 0.001 \\
\hline NDVI & 2 & 1.2 & 0.19 \\
\hline NDMI & 1.8 & 1.1 & 0.264 \\
\hline TWI & 1.2 & 0.8 & 0.878 \\
\hline Overall/CCA Model & $\mathbf{3 1 . 8}$ & $\mathbf{2 . 8}$ & $\mathbf{0 . 0 0 1}$ \\
\hline CCA-Axis-1 & 14.82 & 7.3 & 0.001 \\
\hline CCA-Axis-2 & 5.18 & 2.7 & 0.001 \\
\hline CCA-Axis-3 & 3.99 & 2.2 & 0.007 \\
\hline CCA-Axis-4 & 2.94 & 1.7 & 0.093 \\
\hline CCA-Axis-5 & 2.11 & 1.2 & 0.533 \\
\hline CCA-Axis-6 & 1.65 & 1 & 0.771 \\
\hline CCA-Axis-7 & 0.95 & 0.6 & 0.977 \\
\hline
\end{tabular}

\section{Discussion}

Phytosociological approaches are commonly used to assess the abundance, composition and classification of the weed species of agricultural crops (Anderson, 1996; Qureshi and Bhatti, 2001; Hussain et al., 2004; Jakhar et al., 2005; Hussain et al., 2007; Waheed et al., 2009; Iqbal et al., 2015; Iqbal et al., 2018). Such studies play an important role in the development of weed management to increase the agricultural yield. Additionally, invasiveness capabilities especially of the alien weeds can disrupt local biodiversity (Shabbir and Bajwa, 2006), thus their management is essential to avoid hazardous impacts especially on the crop yield. The satellite remote sensing (SRS) data can be used to study the different bio-physical features of planet earth like vegetation pattern, land cover changes and classification, agricultural yield, land surveying, hydrology and geology etc. For this, different measures like NDVI, NDMI and TWI can be calculated to assess the past, present and future scenario. Sultana et al. (2014) used NDVI values for prediction of wheat crop yield under varied experimental treatments like fertilization and cultivars quality. Thus use of these indices is common to seek vegetation pattern or in the prediction of crop yield pattern. Instead, this novel study was designed to use seasonality (micro-climatic variations) and satellite derived measurements for the exploration of their relationship with the weed distribution pattern of an agro-ecosystem (if any) of Gujrat, Pakistan.

A rich diversity of weed flora was recorded associated with the two important crops (wheat and maize) in district Gujrat, Pakistan. A total of 60 weed species were recorded and the majority of them belongs to Poaceae and Amaranthaceae families (Fig. 2). Iqbal et al. (2015) also recorded the dominancy of Poaceae weeds in the wheat crop from Malakand area of Pakistan. The majority of weed species flowered during monsoon season (July to August) due to micro-climatic suitability like higher temperature along with increased rainfall. Similar results were also recorded by Khan et al. (2018) from 
Muzaffarabad, Azad Jammu and Kashmir, Pakistan. Thus, during this season, therophytic weed species (42 spp., 70\%) having microphyllous leaf size (25 spp., 42\%) becomes dominant (Fig. 8). Similarly Kovačević et al. (2008) also concluded that therophytic weeds group was the dominant character from Herzegovina vineyard region.

Qureshi and Bhatti (2001), Hussain et al. (2004), Jakhar et al. (2005), Waheed et al. (2009), Iqbal et al. (2017) and Iqbal et al. (2018) recorded 5, 3, 3, 5, 5 and 5 weed communities respectively in the wheat fields whereas Ahmad et al. (2016a and 2016b) recorded 4 weed communities each from maize fields of different regions of Pakistan. The decision about the number of the weed communities in the aforementioned studies was made on physiognomic basis and no test statistics was employed. Thus, results of this study about the number of weed groups in both wheat and maize crops do not match with any earlier studies especially from related areas of Pakistan. By using the Monte Carlo testing, this study identified a total of four significant weed groups (Fig. 4), two each in wheat and maize fields, followed by hierarchical clustering for classification (Figs. 5 and 6 ) and indicator species analysis for species composition and their strength of association with the each group (Table 2). The same groups were further confirmed through MRPP testing (Table 3). Thus, weed species composition of each group of this study appeared distinct when compared with the earlier studies. However, the status of overall dominant weed species of both types of crops (i.e. Anagallis arvensis, Medicago polymorpha, Phalaris minor, Chenopodium album, Convolvulus arvensis and Vicia sativa weed species of wheat and Cyperus rotundus, Malva parviflora, Amaranthus graecizans subsp. silvestris, Cannabis sativa, Cynodon dactylon and Digera muricata weed species of maize fields) of this study was mostly comparable and remained the same. On the basis of seasonality difference, 9 weed species were found common in both wheat (winter season weeds) and maize (monsoon season weeds) fields. Out of these, four species named Anagallis arvensis, Convolvulus arvensis, Solanum americanum and Tribulus terrestris showed their maximum abundance in samples recorded from the wheat fields, thus appeared as indicator of the wheat communities. Similarly, based on abundance, the other five common weed species including Cyperus rotundus, Malva parviflora, Cannabis sativa, Cynodon dactylon and Sorghum halepense were become indicator of the maize communities (Table 2). The diversity values like Margalef richness, Shannon's diversity $\left(\mathrm{H}^{\prime}\right)$, Simpson's diversity or Pielou evenness for each of weed community and their significance testing by using a nonparametric test (Kruskal-Wallis H test) was performed for the first time from Pakistan. These results depicted that longitude, NDVI, NDMI, reciprocal Simpson's diversity, Pielou evenness Simpson's diversity, altitude and latitude values (in decreasing order) of the studied fields of the four weed communities were significant ( $p$-value $\leq 0.05$ ). The highest mean weed diversity values were recorded for the maize field communities in monsoon season (Fig. 7). However, contribution of each studied variable for explaining variations in the species data was tested by using CCA ordination model. Results of CCA suggested that the local micro-climatic conditions (seasonality factor) were to be the most important in controlling the variations in the weed species data. By using CCA, Ahmad et al. (2016a) reported the importance of organic matter, potassium, sandy soil and farming practices as driving factor in controlling the weed distribution pattern 


$$
-3015 \text { - }
$$

in maize fields of Mardan, Pakistan. Similarly Iqbal et al. (2018) reported the importance of temperature, electrical conductivity, soil structure, organic matter, lime content, preceding crops, soil $\mathrm{pH}$, herbicides usage, timing and quantity of manure as driving factor in wheat fields of Malakand, Pakistan.

No significant contribution of the NDVI, NDMI and TWI variables was recorded towards explaining the variations in the weed species data (Table 4). This depicted that crop health would be related to satellite derived measures undoubtedly but due to too much higher abundance of the wheat or maize individuals in comparison to their competing weed species individuals in the fields, these explanatory variables were not significant predictors of weed distribution pattern in any agro-ecosystem. The higher NDVI and NDMI values were recorded for the maize field communities in the monsoon season depicting higher greenness and moisture, whereas higher mean TWI value was recorded for the wheat fields, thus suggesting a strong linkage with the local microclimatic conditions (Fig. 7). The overall variations of the SRS variables in the study area are also presented (Fig. 10).

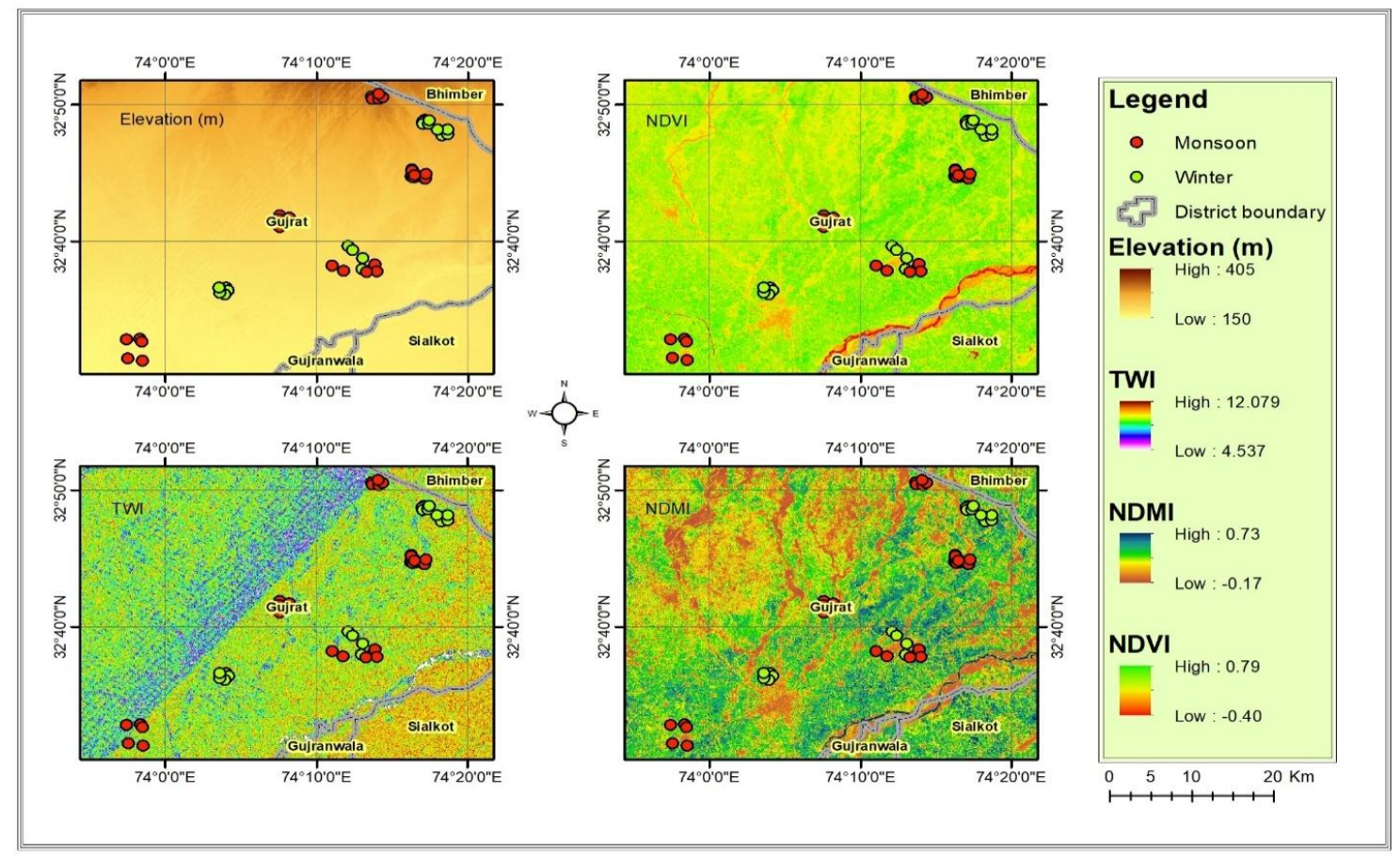

Figure 10. Map showing satellite derived measurement variations in the study area of Gujrat,

Pakistan during 2016.

This study concluded that effective weed management activities are required to further enhance the yield of these two important crops in the area. Similarly, further studies related to determination of weed types and their distribution pattern by using factors like fertilization (type, timing, quantity), wheat and maize cultivar, land preparation (types, timing and intensities), soil management, pesticides (usage, type, quantity, quality), irrigation (type like rain-fed, tube-well, canals; timing, quantity), socio-economic and anthropogenic activities, and their relationship with the yield variable on temporal and spatial scales are recommended. 


\section{REFERENCES}

[1] Ahmad, Z., Khan, S. M., Abd_Allah, E. F., Alqarawi, A. A., Hashem, A. (2016a): Weed species composition and distribution pattern in the maize crop under the influence of edaphic factors and farming practices: A case study from Mardan, Pakistan. - Saudi J. Biol. Sci. 23(6): 741-748.

[2] Ahmad, Z., Khan, S. M., Ali, S., Rahman, I. U., Ara, H., Noreen, I., Khan, A. (2016b): Indicator species analyses of weed communities of maize crop in district Mardan, Pakistan. - Pak. J. Weed Sci. Res. 22(2): 227-238.

[3] Algandaby, M. M., Salama, M. (2016): Management of the noxious weed; Medicago polymorpha L. via allelopathy of some medicinal plants from Taif region, Saudi Arabia. Saudi J. Biol. Sci. https://doi.org/10.1016/j.sjbs.2016.02.013.

[4] Ali, S. I., Qaiser, M. (1995-2009): Flora of Pakistan. - Department of Botany, University of Karachi, Karachi, Pakistan.

[5] Anderson, W. P. (1996): Weed Science: Principles and Applications. - West Publishing Co., Eagan, Minnesota, USA.

[6] Anonymous. (2018): Agricultural profile of district Gujrat, department of agriculture and livestock, Govt. of Punjab, Pakistan. - URL: https://agrihunt.com/articles/pak-agrioutlook/agricultural-profile-of-district-gujrat/ (last accessed 13-02-2018).

[7] Ashique, M., Shah, M. L., Shafi, M. (1997): Weeds of maize and their eradication. Zarat Nama 35(4): 29-32.

[8] Beven, K. J., Kirkby, M. J. (1979): A physically based, variable contributing area model of basin hydrology. - Hydrolological Science Bulletin 24(1): 43-69.

[9] DCR. (2017): District Census Report of Gujrat. - Population Census Organization, Statistics Division, Government of Pakistan Islamabad.

[10] Dufrêne, M., Legendre, P. (1997): Species assemblages and indicator species: the need for a flexible asymmetrical approach. - Ecological monographs 67(3): 345-366.

[11] EFLORAS. (2012): Flora of Pakistan. URL:http://www.efloras.org/flora_page.aspx?flora_id=5 (last accessed 15/10/2017).

[12] FAO. (2017): Food and Agriculture Organization of the United Nations. - URL: http://www.fao.org/giews/countrybrief/country.jsp?code=PAK (Last accessed 12-012018).

[13] Ganie, M. A., Nusrath, D. A. (2016): Determining the Vegetation Indices (NDVI) from Landsat 8 Satellite Data. - Int. J. Adv. Res. 4(8): 1459-1463.

[14] Gao, B. C. (1996): NDWI-A normalized difference water index for remote sensing of vegetation liquid water from space. - Remote sensing of environment 58(3): 257-266.

[15] Hussain, F., Murad, A., Durrani, M. J. (2004): Weed communities in the wheat fields of Mastuj, District Chitral, Pakistan. - Pak. J. Weed Sci. Res. 10(3-4): 101-108.

[16] Hussain, Z., Marwat, K. B., Saeed, M., Gul, B., Khalil, M. R. (2007): Survey on weed problem in wheat crop in district Chitral (a higher altitude area) of NWFP-Pakistan. Pak. J. Weed Sci. Res. 13(1-2): 121-127.

[17] Iqbal, M., Khan, S., Khan, M. A., Rahman, I. U., Abbas, Z., Zahidullah. (2015): Exploration and inventorying of weeds in wheat crop of the district Malakand, Pakistan. Pak. J. Weed Sci. Res. 21(3): 435-452.

[18] Iqbal, M., Khan, S. M., Khan, M. A., Ahmad, Z., Abbas, Z., Khan, S. M., Khan, M. S. (2017): Distribution pattern and species richness of natural weeds of wheat in varying habitat conditions of district Malakand, Pakistan. - Pakistan Journal of Botany 49(6): 2371-2382.

[19] Iqbal, M., Khan, S. M., Khan, M. A., Ahmad, Z., Ahmad, H. (2018): A novel approach to phytosociological classification of weeds flora of an agro-ecological system through Cluster, Two Way Cluster and Indicator Species Analyses. - Ecological Indicators 84: 590-606. 
[20] Jakhar, G. S., Abro, S. A., Maher, A. Q., Qureshi, R. (2005): Weed communities of wheat crop under diverse edaphogropghy of district Khairpur, Pakistan. - Pak. J. Bot. 37(3): 709-714.

[21] Khan, A. M., Ahmed, I., Qureshi, R. A., Qureshi, R., Potter, D., Saqib, Z., Leghari, M. K. (2017): Multivariate analyses of algal diversity from highly polluted sites of Sawan River Rawalpindi, Pakistan. - Pak. J. Weed Sci. Res. 23(4): 413-430.

[22] Khan, A. M., Qureshi, R., Arshad, M., \& Mirza, S. N. (2018): Climatic and flowering phenological relationships of Western Himalayan Flora of Muzaffarabad District, Azad Jammu and Kashmir, Pakistan. - Pak. J. Bot. 50(3): 1093-1112.

[23] Khan, A. M., Qureshi, R., Qaseem, M. F., Munir, M., Ilyas, M., Saqib, Z. (2015): Floristic checklist of district Kotli, Azad Jammu \& Kashmir. - Pak. J. Bot. 47(5): 19571968.

[24] Khan, A. M., Qureshi, R., Qaseem, M. F., Ahmad, W., Saqib, Z., Habib, T. (2016): Status of basic taxonomic skills in botanical articles related to Azad Jammu and Kashmir, Pakistan: A Review. - J. Bioresource Manage. 3(3): 22-54.

[25] Kovačević, Z., Petrović, D., Herceg, N. (2008): The summer aspect of weed flora in the vineyards of Herzegovina. Herbologia 9(2): 9-20.

[26] Magurran, A. E. (1988): Why diversity? In Ecological diversity and its measurement, (pp: 1-5). - Springer, Dordrecht.

[27] Malik, M. A., Zahoor, F., Abbas, S. H., Ansar, M. (2006): Comparative study of different herbicides for control of weeds in rainfed maize (Zea mays L.). - Weed Sci. Soc. Pak. 62.

[28] Margalef, R. (1958): Temporal succession and spatial heterogeneity in phytoplankton (pp. 323-347). In: Perspectives in Marine Biology. - University of California Press, Berkeley 4, California.

[29] McCune, B., Mefford, M. J. (2006): PC-ORD. Multivariate analysis of ecological data. MjM Software Design, Gleneden Beach, Oregon, USA.

[30] McCune, B., Grace, J. B., Urban, D. L. (2002): Analysis of ecological communities. MjM software design, Gleneden Beach, Oregon, USA

[31] Nasir, E., Ali, S. I. (1971-1995): Flora of Pakistan. - Department of Botany University of Karachi, Karachi, Pakistan.

[32] Parvaiz, M. (2014): Ethnobotanical studies on plant resources of Mangowal, District Gujrat, Punjab, Pakistan. - Avicenna J. Phytomedicine 4(5): 364-370.

[33] Pielou, E. C. 1975. Ecological diversity. - Wiley, New York.

[34] Qureshi, R., Bhatti, G. R. (2001): Determination of Weed Communities in Wheat (Triticum aestivum L.) Fields of District Sukker. - Pak. J. Bot. 33(1): 109-115.

[35] R Core Team. (2017): R: A language and environment for statistical computing. - R Foundation for Statistical Computing, Vienna, Austria. ISBN 3-900051-07-0, URL:http://www.R-project.org/.

[36] Shabbir, A., Bajwa, R. (2006): Distribution of Parthenium weed (Parthenium hysterophorus L.), an alien invasive weed species threatening the biodiversity of Islamabad. - Weed Biology and Management 6(2): 89-95.

[37] Shannon, C. E., Weaver, W. (1949): The Mathematical Theory of Communication (pp. 144). - University of Illinois Press, Urbana, Illinois.

[38] Stewart, R. R. (1972): An Annotated Catalogue of the Vascular Plants of West Pakistan and Kashmir. - Fakhri Printing Press, Karachi.

[39] Sultana, S. R., Ali, A., Ahmad, A., Mubeen, M., Zia-Ul-Haq, M., Ahmad, S., Ercisli, S., Jaafar, H. Z. E. (2014): Normalized difference vegetation index as a tool for wheat yield estimation: A case study from Faisalabad, Pakistan. - The Scientific World Journal DOI: http://dx.doi.org/10.1155/2014/725326.

[40] Ter Braak, C. J. F., Smilauer, P. (2012): Canoco 5. Windows release (5.00). [Software for canonical community ordination]. - Microcomputer Power, Ithaca.

[41] TPL. (2013): The Plant List. (Ver. 1.1). - URL: http://www.theplantlist.org/ (last accessed 13/11/20117). 


$$
-3018-
$$

[42] TROPICOS.

(2012):

Flora

of

Pakistan.

URL: http://www.tropicos.org/NameSearch.aspx?projectid=32 (last accessed 28/10/2017).

[43] Ullah, M. A., Afzal, J., Anwar, M. (2007): Determining range vegetation cover and composition of Pabbi Hills Kharian Range, District Gujrat. - Journal of Applied Sciences, 7(16): 2321-2326.

[44] Waheed, A., Qureshi, R., Jakhar, G. S., Tareen, H. (2009): Weed community dynamics in wheat crop of District Rahim Yar Khan, Pakistan. Pak. J. Bot. 41(1): 247-254.

[45] Wilson, J. P., Gallant, J. C. (2000): Terrain Analysis: Principles and Applications. - John Wiley \& Sons Inc. New York, USA. 